Check for updates

Cite this: RSC Adv., 2019, 9, 31343

\title{
Substituent effects on the stability of the four most stable tautomers of adenine and purine $\uparrow$
}

\author{
Halina Szatylowicz, (DD *a Anna Jezuita, ${ }^{\text {b }}$ Paulina H. Marek ${ }^{\text {ac }}$ \\ and Tadeusz M. Krygowski ${ }^{\mathrm{C}}$
}

Substituent effects at the C2-, C8- and N-positions of adenine and purine in their four the most stable tautomers are studied by means of B97D3/aug-cc-pvdz computation applying substituents of varying electronic properties: $\mathrm{NO}_{2}, \mathrm{CN}, \mathrm{CHO}, \mathrm{Cl}, \mathrm{F}, \mathrm{H}, \mathrm{Me}, \mathrm{OMe}, \mathrm{OH}$ and $\mathrm{NH}_{2}$. The substituent effect is characterized by the substituent effect stabilization energy (SESE) and substituent Hammett constant $\sigma$. For adenine, SESE is obtained with purine as the reference system. Additionally, for both adenine and purine, SESE characteristics are estimated with benzene, imidazole and amino-pyrimidine as reference systems, when possible, taking into account substitution in topologically equivalent positions. The role of a $\mathrm{C} 6-\mathrm{NH}_{2}$ group in adenine in modifying the substitution effect is observed and discussed. Additionally, the proximity effect for some asymmetric substituents (e.g. $\mathrm{CHO}, \mathrm{OMe}$ ) is recognized and meticulously analyzed.

Received 19th June 2019

Accepted 20th September 2019

DOI: 10.1039/c9ra04615a

rsc.li/rsc-advances

ethyladenine and to compare them with the corresponding data for thymine derivatives. Almost at the same time, substituent effects on the optical activity of some purine nucleosides were studied. ${ }^{6}$ The effect of exocyclic substituents of purine bases on the DNA curvature was also reported., ${ }^{7,8}$ The substituent effects at the major and minor grooves of the double helix on the hydration and stability of Z- versus B-DNA were also investigated. ${ }^{9}$ Subsequent studies concerned the influence of the substituent on process of pairing and polymerase recognition of simple unnatural base pairs. ${ }^{10}$

ADF computational package was used to study substituent effects on nanoswitches based on DNA base pairs ${ }^{11}$ and on the NMR shielding constants of complexes based on AT and AU base pairs. ${ }^{12}$ For AT and GC base pairs, systematic studies of the substituent effects on the individual hydrogen bond energies were carried out. ${ }^{13}$ Recently, the effect of the substitution of halogen atoms at the position 8 in adenine $9 \mathrm{H}, 7 \mathrm{H}, 3 \mathrm{H}$ and $1 \mathrm{H}$ tautomers on their relative stability, vibrational frequencies and Raman spectra, were studied by means of DFT at the B3LYP/6$311+G(d, p)$ level of theory. ${ }^{14}$ It was found that the stability of tautomers of substituted adenine molecules strongly depends on solvation. It was also found ${ }^{15}$ that, for 20 different substituents in the position 8 of adenine, electrostatic potentials at the bonding atoms of monomers correlate nicely with interaction energies of adenine-thymine pairs.

All of the above-mentioned papers present research results indicating that many important properties of nucleic acid bases significantly depend on the substituent attached to their molecules. In addition, it should be mentioned that in most cases observed changes of the studied systems were not related to the electron properties of substituents. It is well known that

${ }^{a}$ Faculty of Chemistry, Warsaw University of Technology, Noakowskiego 3, 00-664 Warsaw, Poland.E-mail: halina@ch.pw.edu.pl

${ }^{b}$ Faculty of Chemistry, Opole University, Oleska 48, 45-052 Opole, Poland 'Faculty of Chemistry, University of Warsaw, Pasteura 1, 02-093 Warsaw, Poland

$\dagger$ Electronic supplementary information (ESI) available. See DOI: 10.1039/c9ra04615a 
<smiles>Nc1ncnc2c1N=CNN2</smiles>

$9 \mathrm{H}$ adenine<smiles>C1=Nc2cncnc2NN1</smiles>

9H purine<smiles>Nc1ncnc2nc[nH]c12</smiles>

7H adenine<smiles>c1ncc2[nH]cnc2n1</smiles>

7H purine<smiles>Nc1nc[nH]c2ncnc1-2</smiles>

3H adenine<smiles></smiles>

$3 \mathrm{H}$ purine<smiles>Nc1[nH]cnc2ncnc1-2</smiles>

$1 \mathrm{H}$ adenine<smiles>c1nc2c[nH]cnc-2n1</smiles>

$1 \mathrm{H}$ purine

Scheme 1 Structures and numbering scheme of four the most energetically favorable adenine and purine tautomers.

substituents can exert either electron withdrawing or electron donating properties. Thus, they may influence substituted systems in a different way and have a fundamental impact on the nature and consequences of the substituent effect. ${ }^{16}$

Classically, the quantitative characteristics of the substituent effect is described by the Hammett substituent constants $\sigma$ (ref. 17 and 18) or their modifications. ${ }^{19}$ Positive values of $\sigma$ denote that the substituent is electron-attractive, while negative ones stand for electron-donating properties. Substituent constants have great utility in the so-called Hammett equation, where physicochemical properties of the substituted systems $P(\mathrm{X})$ are linearly related to the substituent constants $\sigma(\mathrm{X})$, as shown in eqn (1)

$$
P(\mathrm{X})=\rho \sigma(\mathrm{X})+\text { const }
$$

where $\rho$ is termed reaction constant and characterizes sensitivity of the property $P(\mathrm{X})$ on influence of the substituent $\mathrm{X}$. For exhaustive reviews see ref. 16 and 20-23.

Dynamic development of applications of quantum chemistry in chemical research ${ }^{24,25}$ has resulted in the introduction of several models based on quantum chemistry describing substituents effects. One of them is the use of homodesmotic reactions ${ }^{26-28}$ which for disubstituted species is presented by eqn (2)

$$
\mathrm{X}-\mathrm{R}-\mathrm{Y}+\mathrm{R} \rightarrow \mathrm{R}-\mathrm{X}+\mathrm{R}-\mathrm{Y}
$$

The difference between energy of products and substrates, named SESE (substituent effect stabilization energy), ${ }^{29}$ describes the substituent effect in energetic scale. A positive SESE value means that the intramolecular interactions between the substituents $\mathrm{X}$ and $\mathrm{Y}$ stabilize the $\mathrm{X}-\mathrm{R}-\mathrm{Y}$ system. This descriptor of the substituent effect takes into account all interactions in $\mathrm{X}-\mathrm{R}-\mathrm{Y}$ systems. Another quantum chemistry concept of the substituent effect is based on atomic charges. It is known that due to polarity of $\mathrm{X}-\mathrm{C}$ bonds in substituted carbocyclic systems, atomic charges of substituents (in e.g. benzene derivatives) do not correlate with substituent constants. ${ }^{30}$ However, when instead of the charge of the $\mathrm{X}$ substituent, $q(\mathrm{X})$, the sum of charges in the substituent $\mathrm{X}$ and the ipso carbon atom are taken into account, the correlations with the constant substituents are very good. ${ }^{31,32}$ This descriptor is named $\operatorname{cSAR}(\mathrm{X})$ (charge of the substituent active region) and independently of the atomic charge assessment method, it correlates well with substituent constants. ${ }^{33}$ Recently, it has been shown that in the case of series of disubstituted benzene, cyclohexadiene and bicyclooctane derivatives, both descriptors, SESE and $\operatorname{cSAR}(\mathrm{X})$, modeled theoretically correlate well with traditional substituent constants. ${ }^{29,34-36}$ It is important to note that $\operatorname{cSAR}(\mathrm{X})$ not only describes electron attracting/donating properties of the substituent, but also informs how these properties depend on its position in the substituted molecule. Another fruitful theoretical tool to study the substituent effect is the analysis of molecular electrostatic potential (MESP), which was recently published by Remya and Suresh ${ }^{37}$ and references therein.

Adenine and purine are $\pi$-electron systems. As mentioned above, four endocyclic nitrogen atoms with the possibility of prototropic rearrangements give four tautomers. There are several questions that we should ask here: (i) how substituent effect descriptors based on quantum chemistry work in such complex molecules and whether they differ from benzene systems; (ii) how the substituent effect works in four different tautomers; (iii) whether the substituent can change the stability of the tautomer; (iv) how far the amino group in adenine may differentiate the substituent effect comparing to purine.

\section{Methodology}

The research objects were $\mathrm{C} 2-\mathrm{X}, \mathrm{C} 8-\mathrm{X}$ and $\mathrm{N}-\mathrm{X}$ substituted derivatives (where $\mathrm{X}=\mathrm{NO}_{2}, \mathrm{CN}, \mathrm{CHO}, \mathrm{Cl}, \mathrm{F}, \mathrm{H}, \mathrm{Me}, \mathrm{OMe}, \mathrm{OH}$ and $\mathrm{NH}_{2}$ ) of the four most stable adenine and purine tautomers (Scheme 1). In the case of asymmetrical substituents (CHO, $\mathrm{OMe}$ and $\mathrm{OH}$ ), both rotamers were taken into account, the one 
with the lower energy was used for SESE calculations. For all studied systems, optimization without any symmetry constraints was performed using the Gaussian 09 package. ${ }^{38}$ According to the results of our previous research, ${ }^{39}$ the DFT-D methods were used, that is functionals B97D3 (ref. 40) and $\omega \mathrm{B} 97 \mathrm{XD},{ }^{41}$ both with Dunning's aug-cc-pvdz basis set. ${ }^{42}$ To confirm that calculated structures correspond to the minima on the potential energy surface the vibrational frequencies were calculated at the same level of theory. No imaginary frequencies were found for the obtained systems. Since the results of calculations obtained on both calculation levels are very similar, in the further part of the work the first ones (B97D3/aug-ccpvdz) are presented and discussed.

\section{Results and discussion}

Adenine and purine are closely related to each other structurally, differing only in the amino group in the position 6 of purine. Their four most stable tautomers are realized by migration of the proton between the nitrogen atoms in positions 9, 7, 3 and 1 and are named $9 \mathrm{H}, 7 \mathrm{H}, 3 \mathrm{H}$ and $1 \mathrm{H}$, respectively (Scheme 1).

The energy changes due to the presence of the most electronaccepting and electron-donating substituents $\left(\mathrm{NO}_{2}\right.$ and $\mathrm{NH}_{2}$, respectively) in purine and adenine are presented in Fig. 1; the data are shown in the order: $9 \mathrm{H}, 7 \mathrm{H}, 3 \mathrm{H}$ and $1 \mathrm{H}$.

For all presented derivatives, it is clearly visible that the substitution of the $\mathrm{C}-\mathrm{X}$ type causes a decrease in the energy of the system as compared to the substitution at the nitrogen atom
$(\mathrm{N}-\mathrm{X})$. Moreover, significant differences can be noticed when looking at the nitro and amino derivatives substituted at the C2 and C8 positions. In the case of the C2- and C8-nitro purine derivatives tautomer energies increase monotonically, while for adenine derivatives the lines are irregular and intersect between $7 \mathrm{H}$ and $3 \mathrm{H}$ tautomers. For amino derivatives of purine and adenine energy changes are similar. In both cases substitution at $\mathrm{C} 2$ leads to lower stability of $3 \mathrm{H}$ and $1 \mathrm{H}$ tautomers than in the case of C8 substitution. This means that the amino group affects energy of substituted tautomer derivatives strongly enough to modify the sequence of decreased stability. For the $\mathrm{N}-\mathrm{X}$ systems shown in Fig. 1, the most significant changes in tautomer stability are observed for nitro-substituted purine derivatives, discussed below.

Relative energy values, $E_{\text {rel }}$, (with respect to the $9 \mathrm{H}$ tautomer $9 \mathrm{H}$ ), for studied C8-X, C2-X and N-X substituted derivatives of adenine and purine tautomers can be found in Tables S1-S3. $\dagger$ Firstly, obtained results show that in all cases, the $9 \mathrm{H}$ tautomer is the most stable for both adenine and purine derivatives. The only exception is 7- $\mathrm{NO}_{2}$-purine, more stable than 9- $\mathrm{NO}_{2}$-purine by $c a .1 .7 \mathrm{kcal} \mathrm{mol}^{-1}$, and the reason is a formation of a weak $\mathrm{C}-\mathrm{H} \cdots \mathrm{O}$ intramolecular hydrogen bond in the former. The mean values of average relative stability in substituted adenines is $\sim 10 \mathrm{kcal} \mathrm{mol} \mathrm{m}^{-1}$, whereas for purine series is only $\sim 7.3 \mathrm{kcal} \mathrm{mol}^{-1}$. Undoubtedly, this difference results from the presence of the $\mathrm{NH}_{2}$ group at the 6-position in adenine, which additionally leads to greater variability of relative energies in adenine series. Secondly, we noted that for both adenine and

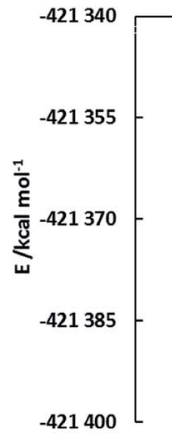

a)

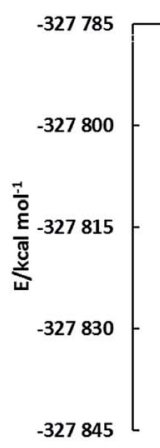

b)
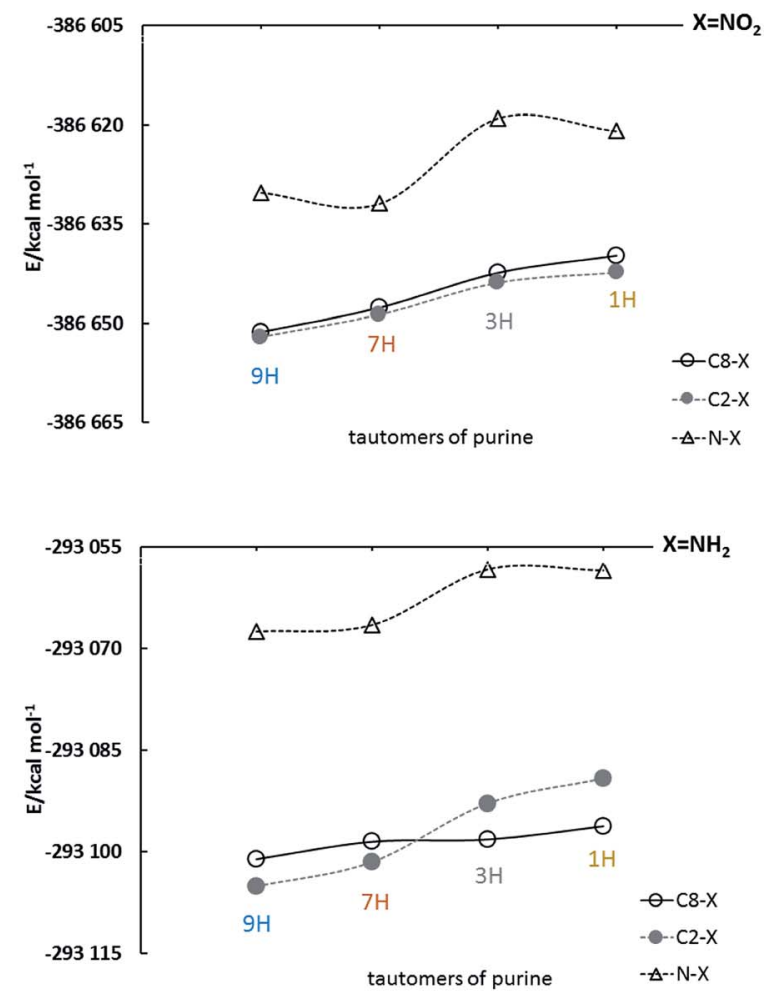

Fig. 1 Energy changes of adenine and purine tautomers in sequence: $9 \mathrm{H}, 7 \mathrm{H}, 3 \mathrm{H}, 1 \mathrm{H}$ for (a) $\mathrm{NO}_{2}$ and (b) $\mathrm{NH}_{2}$ substituted derivatives; for clarity, the points are connected by a solid or dashed line. 
purine derivatives, in both $\mathrm{C} 8$ and $\mathrm{C} 2$ substituent positions, the $E_{\text {rel }}$ values for tautomers $7 \mathrm{H}$ have the smallest range of variation (2.91 and $0.99 \mathrm{kcal} \mathrm{mol}^{-1}$ for adenine, and 1.15 and $0.59 \mathrm{kcal} \mathrm{mol}^{-1}$ for purine, respectively). The direct neighborhood of the $\mathrm{C} 8$ substituent in $9 \mathrm{H}$ and $7 \mathrm{H}$ tautomers is almost identical: one nitrogen atom with a lone pair in the molecular plane $\left(2 \mathrm{p}_{x y}\right)$ and one electron on the perpendicular $2 \mathrm{p}_{z}$ orbital and second nitrogen (in $\mathrm{N}-\mathrm{H}$ group) with $2 \mathrm{p}_{z}$ electron pair. Thus, even if there are some proximity effects, they are similar, and the resulting $E_{\text {rel }}$ differences are small. For C2-X substitution the ranges are the smallest, since there are no proximity effects that appear in the vicinity of C8. No such situations are found in other cases, with much larger $E_{\text {rel }}$ ranges, generally between $8.07 \mathrm{kcal} \mathrm{mol}^{-1}$ (3H, C8-X substitution in adenine) and $13.21 \mathrm{kcal} \mathrm{mol}^{-1}(1 \mathrm{H}, \mathrm{C} 2-\mathrm{X}$ substitution in adenine). In addition, it is worth noting that the substituents, except for the $\mathrm{N}-\mathrm{X}$ cases with $\mathrm{X}=\mathrm{NO}_{2}$, do not change the stability of purine tautomers (Tables S2 and S3 $\dagger$ ), which decreases in order of H9, $\mathrm{H} 7, \mathrm{H} 3$ and $\mathrm{H} 1$.

\section{Substituent effect (SE) descriptor based on relative stability of tautomer}

The use of relative energy $\left(E_{\text {rel }}\right)$ differences with respect to the unsubstituted systems $(\mathrm{X}=\mathrm{H})$ allow for easier analysis of the SE. For $7 \mathrm{H}$ tautomers, this difference can be written as the energy of the homodesmotic reaction, named $\mathrm{SESE}_{\text {rel}}$ :

$$
\begin{gathered}
9 \mathrm{H}-\mathrm{X}+7 \mathrm{H} \rightarrow 7 \mathrm{H}-\mathrm{X}+9 \mathrm{H} \\
\mathrm{SESE}_{\text {rel }}=E_{7 \mathrm{H}-\mathrm{X}}+E_{9 \mathrm{H}}-\left(E_{9 \mathrm{H}-\mathrm{X}}+E_{7 \mathrm{H}}\right) \\
=E_{\text {rel }} 7 \mathrm{H}-\mathrm{X}-E_{\text {rel }} 7 \mathrm{H}
\end{gathered}
$$

Analogous equations can be written for $3 \mathrm{H}$ and $1 \mathrm{H}$ tautomers. The obtained $\mathrm{SESE}_{\text {rel }}$ values for $7 \mathrm{H}, 3 \mathrm{H}$ and $1 \mathrm{H}$ substituted adenine and purine tautomers are gathered in Tables 1 and 2, while the comparison of the substituent effect observed for adenine and purine derivatives is shown in Fig. 2; in addition, the statistics of obtained linear regressions are collected in Table S4. $\dagger$

To reveal the influence of the presence of the amino group on the substituent effect the dependencies of $\mathrm{SESE}_{\mathrm{rel}}$ (adenine) on $\mathrm{SESE}_{\text {rel }}$ (purine) are analyzed (Fig. 2 and Table $\mathrm{S} 4 \dagger$ ). Three substitution positions are shown: $\mathrm{C} 8-\mathrm{X}, \mathrm{C} 2-\mathrm{X}$ and $\mathrm{N}-\mathrm{X}$. For the $\mathrm{C}-\mathrm{X}$ series, a slope greater than 1.00 has been found for derivatives of $7 \mathrm{H} \mathrm{C} 8-\mathrm{X}$ and $1 \mathrm{H} \mathrm{C} 2-\mathrm{X}$, its values are $2.45( \pm 0.14)$ and $1.176( \pm 0.040)$, respectively. In both cases $\mathrm{NH}$ is located near the amino group of adenine and a substituted carbon atom. In other cases, the slopes are lower than 1.0. In all C-X cases $R^{2}>$ 0.9 , with the exception of $7 \mathrm{H} \mathrm{C2-X}$ systems.

Relationships between $\mathrm{SESE}_{\text {rel }}$ values (adenine vs. purine) of $\mathrm{N}-\mathrm{X}$ substituted tautomers do not lead to unequivocal conclusions. However, when some of the most deviating points are omitted (empty circles in Fig. 2c), the reasonable correlations can be noticed. The slope is the highest for $7 \mathrm{H}(1.15 \pm 0.15$, without $\mathrm{X}=\mathrm{CHO}$ ) then $0.71( \pm 0.12)$ for $1 \mathrm{H}$ (without $\mathrm{X}=\mathrm{NO}_{2}$ and $\mathrm{OH})$ and finally $0.673\left( \pm 0.031, R^{2}=0.983\right)$ for $3 \mathrm{H}$ substituted tautomers.
Thus, the comparison of the substituent effect, based on $\mathrm{SESE}_{\mathrm{rel}}$ model, in adenine with that present in purine, allows to conclude that more significant effect is observed in adenine when substituent is attached to the 5-membered ring.

Hammett $\sigma$ constants are the most commonly used to describe the electron donating/accepting properties of the substituents. Their application to the data in Tables 1 and 2, this is $\mathrm{SESE}_{\text {rel }} v s$. $\sigma$ regression (see Table S5†), leads to the observation that in the case of $\mathrm{C} 8-\mathrm{X}$-substituted $7 \mathrm{H}$ tautomer, both adenine and purine, the determination coefficients are 0.878 and 0.810 , respectively, with a large difference in the slope values: $2.206( \pm 0.291)$ and $0.855( \pm 0.147)$, respectively. This difference in the slopes can be related to a significant influence of the amino group in adenine on charge transfer from the substituent to the molecular moiety. It is important to note that in addition to these results, all other linear regressions with substituent constants always lead to $R^{2}$ lower than 0.3 (for $3 \mathrm{H}$ C8-X purine series). These results provide important information that the model of interactions which describes well the substituent effect in benzene derivatives fails completely in some cases of adenine and purine derivatives. This problem will be discussed in more details later.

\section{Comparison of substituent effects from positions C8 and C2}

Differences between the energies of pairs of the same molecule with different substitution positions allow to compare the substituent effect from these positions. For all adenine and purine tautomer series with substituents at the $\mathrm{C} 8-\mathrm{X}$ and $\mathrm{C} 2-\mathrm{X}$ positions

$$
\Delta E_{8-2}=E_{\mathrm{C} 8-\mathrm{X}}-E_{\mathrm{C} 2-\mathrm{X}}
$$

where $E_{\mathrm{C} 8-\mathrm{X}}$ and $E_{\mathrm{C} 2-\mathrm{X}}$ are the energies of the mono-substituted molecule at positions $\mathrm{C} 8-\mathrm{X}$ and $\mathrm{C} 2-\mathrm{X}$, respectively.

It should be noticed that the close vicinity of $\mathrm{C} 2$ and $\mathrm{C} 8$ substitution positions in adenine and purine is topologically identical. The obtained $\Delta E_{8-2}$ values for all adenine and purine tautomers are given in Tables 3 and 4, respectively.

Some interesting points resulting from the comparison of the data presented in Tables 3 and 4 can be discussed. In both series (adenine and purine), for $7 \mathrm{H}$ and $9 \mathrm{H}$ tautomers the differences are positive (except for $\mathrm{CHO}$ and Me derivatives), and for $1 \mathrm{H}$ and $3 \mathrm{H}$ are mostly negative, what can be seen in the averaged data for all substituents. The mean values of $\Delta E_{8-2}$ averaged for all four tautomers of adenine and purine derivatives do not correlate with each other $\left(R^{2}=0.421\right)$, while the range values do very well $\left(R^{2}=0.954\right)$, as shown in Fig. S1. $\dagger$ This can be interpreted as follows: the nature of interactions caused by the substituent is different in purine and adenine, but the strength of the interactions is alike.

Fig. 3 presents a comparison of the obtained $\Delta E_{8-2}$ values for adenine and purine - in other words - shows how the amino group in adenine influences interactions in the molecules. As mentioned above, the closest vicinity of positions C2 and C8 (Scheme 1) is similar. Either there are two nitrogen atoms with one $\pi$-electron and a lone pair in the plane of the molecule, or there is one $\mathrm{N}$-atom of this kind and $\mathrm{NH}$ group, with $2 \mathrm{p}_{z}$ electron pair. Obviously, in the first case, in $\mathrm{N}-\mathrm{C} 2-\mathrm{X}-\mathrm{N}$ fragment the nitrogen atoms can act as 
Table 1 The obtained SESE rel (in $\mathrm{kcal} \mathrm{mol}^{-1}$ ) values for $7 \mathrm{H}, 3 \mathrm{H}$ and $1 \mathrm{H}$ adenine and purine tautomers substituted at the $\mathrm{C} 8$ and $\mathrm{C} 2$ positions (Scheme 1)

\begin{tabular}{|c|c|c|c|c|c|c|c|c|c|c|c|c|}
\hline & \multicolumn{6}{|c|}{ Adenine } & \multicolumn{6}{|l|}{ Purine } \\
\hline & \multicolumn{3}{|l|}{ C8-X } & \multicolumn{3}{|l|}{$\mathrm{C} 2-\mathrm{X}$} & \multicolumn{3}{|l|}{ C8-X } & \multicolumn{3}{|l|}{$\mathrm{C} 2-\mathrm{X}$} \\
\hline $\mathrm{NO}_{2}$ & 1.32 & -0.28 & 0.22 & -0.09 & 0.08 & -2.55 & 0.38 & 0.27 & 0.05 & 0.04 & -0.53 & -1.81 \\
\hline $\mathrm{CN}$ & 1.05 & -2.58 & -2.17 & 0.36 & 2.69 & 1.49 & 0.33 & -2.14 & -2.32 & 0.09 & 2.25 & 1.78 \\
\hline $\mathrm{F}$ & -0.47 & -4.62 & -5.57 & 0.12 & 4.72 & 4.82 & -0.18 & -4.84 & -5.80 & -0.14 & 4.43 & 4.28 \\
\hline $\mathbf{H}$ & 0.00 & 0.00 & 0.00 & 0.00 & 0.00 & 0.00 & 0.00 & 0.00 & 0.00 & 0.00 & 0.00 & 0.00 \\
\hline Me & -0.26 & 0.45 & 0.10 & -0.02 & -0.57 & -0.64 & -0.04 & -0.01 & -0.09 & 0.12 & -0.66 & -0.55 \\
\hline OMe & -1.59 & -1.33 & -2.41 & -0.63 & 0.46 & -0.34 & -0.77 & -2.53 & -2.78 & -0.27 & 0.01 & -0.27 \\
\hline $\mathrm{OH}$ & -1.58 & -2.21 & -3.90 & -0.39 & 1.61 & 1.25 & -0.74 & -3.26 & -4.03 & 0.30 & 1.46 & 1.42 \\
\hline $\mathrm{NH}_{2}$ & -1.48 & -3.32 & -5.44 & 0.14 & 3.52 & 4.21 & -0.67 & -5.74 & -6.56 & 0.30 & 3.55 & 4.42 \\
\hline
\end{tabular}

hydrogen bond acceptors, whereas in $\mathrm{NH}-\mathrm{C} 8-\mathrm{X}-\mathrm{N}$ they may play a role of a donor and an acceptor, respectively.

Despite the similarity of the closest vicinity for substituents in the $\mathrm{C} 2-\mathrm{X}$ and $\mathrm{C} 8-\mathrm{X}$ positions and the fact that their energy difference is considered, differences appear in $\Delta E_{8-2}$ for tautomers of adenine and purine. For $1 \mathrm{H}$ and $3 \mathrm{H}$ tautomers interactions are stronger in purine derivatives, and for $7 \mathrm{H}$ and 9H they are stronger in adenine series (Fig. 3). It is important to say that except for the $3 \mathrm{H}$ tautomer in all other cases the substituent effects are well linearly correlated with each other $\left(R^{2}>0.945\right)$ and slopes variety (between 0.868 and 1.256$)$ could indicate dependence of the systems sensibility on the position of the substituent. Undoubtedly, the difference should be related to the presence of $\mathrm{NH}_{2}$ group in adenine.

\section{SESE model based on adenine and purine reactions}

Energies of substituted purine (PU) and adenine (AD) can be applied for homodesmotic reactions:

Table 2 The obtained SESE rel (in kcal mol ${ }^{-1}$ ) values for $7 \mathrm{H}, 3 \mathrm{H}, 1 \mathrm{H}$ adenine and purine tautomers substituted at the $\mathrm{N}-\mathrm{X}$ positions

\begin{tabular}{|c|c|c|c|c|c|c|}
\hline \multirow[b]{2}{*}{$\mathrm{N}-\mathrm{X}$} & \multicolumn{3}{|c|}{ Adenine } & \multicolumn{3}{|l|}{ Purine } \\
\hline & $7 \mathrm{H}$ & $3 \mathrm{H}$ & $1 \mathrm{H}$ & $7 \mathrm{H}$ & $3 \mathrm{H}$ & $1 \mathrm{H}$ \\
\hline $\mathrm{NO}_{2}$ & -5.97 & 2.12 & -0.13 & -4.99 & 2.54 & -2.20 \\
\hline $\mathrm{CN}$ & -3.20 & 3.90 & 0.87 & -1.44 & 4.97 & 3.33 \\
\hline $\mathrm{CHO}$ & -4.87 & 2.20 & 0.18 & -1.11 & 3.79 & 2.27 \\
\hline $\mathrm{Cl}$ & -1.84 & -0.61 & -1.02 & -1.32 & -1.79 & -0.23 \\
\hline $\mathrm{F}$ & -2.88 & -2.56 & -4.10 & -2.08 & -4.22 & -4.48 \\
\hline $\mathbf{H}$ & 0.00 & 0.00 & 0.00 & 0.00 & 0.00 & 0.00 \\
\hline $\mathrm{Me}$ & 0.67 & -0.44 & 1.11 & 0.10 & -0.89 & 1.51 \\
\hline OMe & -2.47 & -1.95 & -3.71 & -0.89 & -3.03 & -2.46 \\
\hline $\mathrm{OH}$ & -1.12 & -3.57 & -2.28 & -0.45 & -5.59 & 0.77 \\
\hline $\mathrm{NH}_{2}$ & -0.09 & -1.23 & -0.56 & 0.73 & -1.60 & 1.52 \\
\hline Range & 6.64 & 7.47 & 5.21 & 5.71 & 10.56 & 7.82 \\
\hline Average & -2.18 & -0.21 & -0.96 & -1.15 & -0.58 & 0.00 \\
\hline SD & 2.04 & 2.34 & 1.73 & 1.59 & 3.45 & 2.41 \\
\hline
\end{tabular}

$$
\begin{gathered}
9 \mathrm{H} \mathrm{C} 8-\mathrm{X}-\mathrm{AD}+9 \mathrm{H} \mathrm{PU} \rightarrow 9 \mathrm{H} \mathrm{AD}+9 \mathrm{H} \mathrm{C} 8-\mathrm{X}-\mathrm{PU} \\
\mathrm{SESE}_{\mathrm{PU}}=E_{9 \mathrm{H}} \mathrm{AD}+E_{9 \mathrm{H}} \mathrm{C} 8-\mathrm{X}-\mathrm{PU} \\
-\left(E_{9 \mathrm{H}} \mathrm{C} 8-\mathrm{X}-\mathrm{AD}\right. \\
\left.-E_{9 \mathrm{H}} \mathrm{PU}\right)
\end{gathered}
$$

For C2-X substituted systems of the $9 \mathrm{H}$ tautomer we can write:

$\mathrm{SESE}_{\mathrm{PU}}=E_{9 \mathrm{H} \mathrm{AD}}+E_{9 \mathrm{H} \mathrm{C} 2-\mathrm{X}-\mathrm{PU}}-\left(E_{9 \mathrm{H} \mathrm{C}-\mathrm{X}-\mathrm{AD}}+E_{9 \mathrm{H} \mathrm{PU}}\right)(6)$

Analogous equations can be written for the remaining substituted tautomers. The results of the $\mathrm{SESE}_{\mathrm{PU}}$ approach are gathered in Table 5. Positive $\mathrm{SESE}_{\mathrm{PU}}$ values indicate greater stability of substrates than reaction products.

Observed $\mathrm{SESE}_{\mathrm{PU}}$ values are usually negative (i.e. destabilizing interactions) for electron-donating substituents and positive for the electron-attracting ones. In the case of strongly interacting substituents, for the C8- $\mathrm{NH}_{2}$ and $\mathrm{C} 2-\mathrm{NH}_{2}$ systems the average $\mathrm{SESE}_{\mathrm{PU}}$ values (in kcal $\mathrm{mol}^{-1}$ ) are -2.47 and -0.46 , whereas 2.37 and 1.72 for $\mathrm{NO}_{2}$ derivatives, respectively. These differences in the energy values of the substituent effects in adenine, in comparison with purine, can be connected to the presence of the amine group at the 6position in adenine.

It is interesting to compare the $\operatorname{SESE}_{\mathrm{PU}}$ values with the traditional substituent effect descriptor, i.e. Hammett constants. Its mutual correlations for $\mathrm{C} 8-\mathrm{X}$ and $\mathrm{C} 2-\mathrm{X}$ adenine series are shown in Fig. 4, in addition, statistical details are presented in Table $\mathrm{S} 6 \dagger$ (for both $\sigma_{\mathrm{p}}$ and $\sigma_{\mathrm{m}}$ relations).

A verification of the obtained interrelationships shows: (i) for C8-X systems SESE $_{\mathrm{PU}}$ correlates better with $\sigma_{\mathrm{p}}$ than with $\sigma_{\mathrm{m}}$, (ii) the same applies to $\mathrm{C} 2-\mathrm{X}$ series of $3 \mathrm{H}$ and $1 \mathrm{H}$ tautomers, when $\mathrm{X}=\mathrm{CHO}$ systems are excluded, whereas (iii) for $\mathrm{C} 2-\mathrm{X}$ derivatives of $9 \mathrm{H}$ and $7 \mathrm{H}$ tautomers, a better correlation of $\mathrm{SESE}_{\mathrm{PU}}$ with $\sigma_{\mathrm{m}}$ than with $\sigma_{\mathrm{p}}$ can be found. 

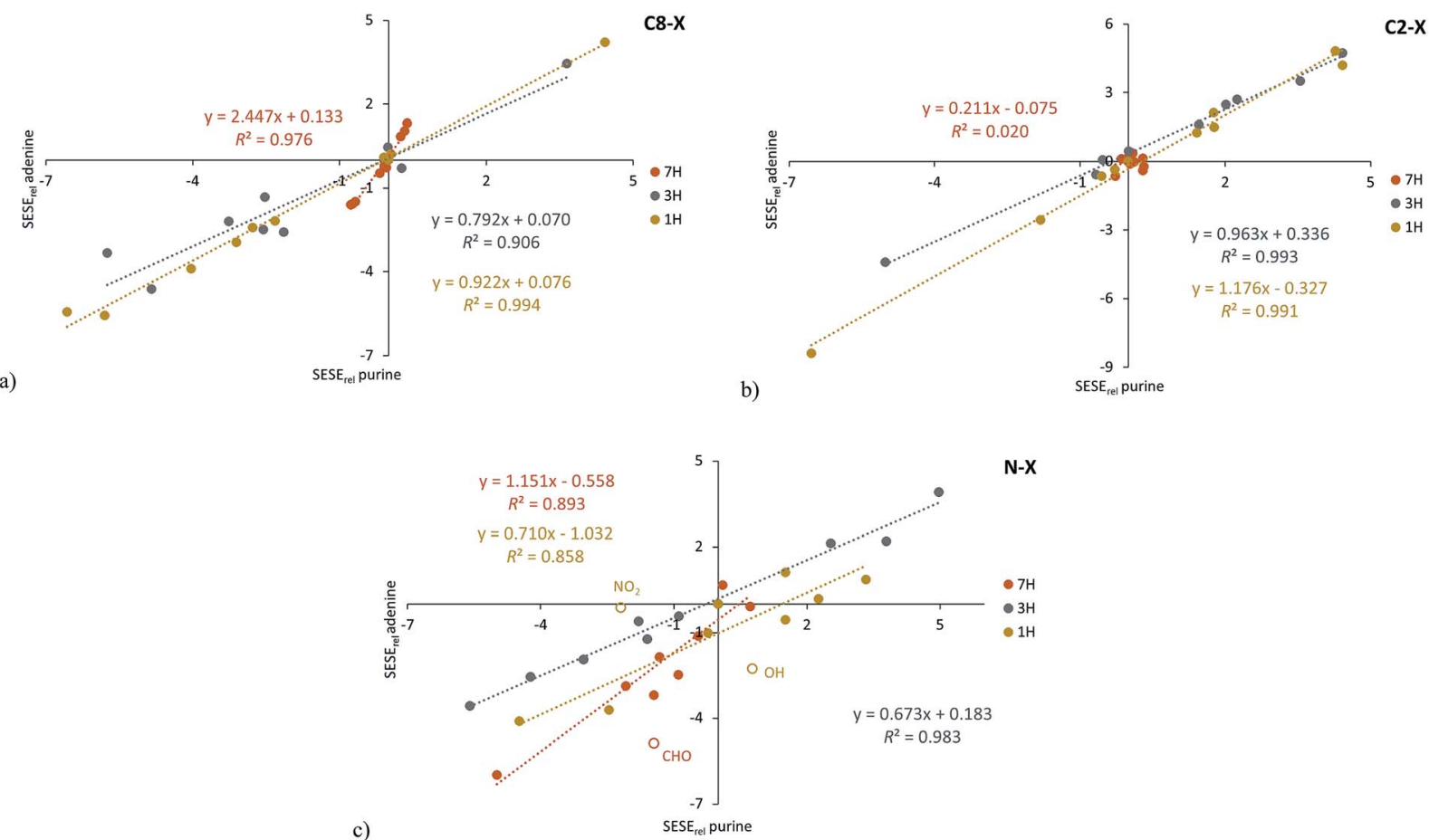

Fig. 2 Correlations between SESE rel values (in kcal mol ${ }^{-1}$ ) of adenine and purine tautomers for C $8-X(a), C 2-X$ (b) and N-X (c) positions of substituents; empty circles indicate substituents not included in the regression.

Since $\mathrm{SESE}_{\mathrm{PU}}$ values are based on differences in the energy values of the analogically substituted adenine and purine derivatives, obtained values inform about changes related to the amino group present in adenine tautomers. In the $7 \mathrm{H}$ tautomer the $2 \mathrm{p}_{z}$ electron pair residing at $\mathrm{N} 7$ atom hinders charge transfer between electron-attracting substituents at the C8 position and the amino group at C6 (Scheme 1). This can be confirmed by the smallest value of the slope for this series. For $9 \mathrm{H}$ tautomers, where there is no such problem with the charge transfer, the interaction is stronger, hence the slope is steeper. The situation is more complex for $3 \mathrm{H}$ and $1 \mathrm{H}$ tautomers and

Table 3 Energy difference values, $\Delta E_{8-2}$ (eqn (4), in $\mathrm{kcal} \mathrm{mol}^{-1}$ ), of the studied C $8-X$ and $C 2-X$ substituted adenine (AD) tautomers

\begin{tabular}{lrrrrrr}
\hline & $\Delta E_{8-2}$ & & & & & \\
\cline { 2 - 5 } $\mathrm{AD}$ & \multicolumn{1}{c}{$9 \mathrm{H}$} & \multicolumn{1}{c}{$7 \mathrm{H}$} & \multicolumn{1}{c}{$3 \mathrm{H}$} & \multicolumn{1}{c}{$1 \mathrm{H}$} & Average & Range \\
\hline $\mathrm{NO}_{2}$ & -0.16 & 1.25 & -0.52 & 2.61 & 0.79 & 3.12 \\
$\mathrm{CN}$ & 0.01 & 0.71 & -5.26 & -3.65 & -2.05 & 5.96 \\
$\mathrm{CHO}$ & -5.70 & -4.64 & 2.17 & 6.92 & -0.31 & 12.62 \\
$\mathrm{Cl}$ & 2.95 & 2.59 & -2.02 & -2.12 & 0.35 & 5.07 \\
$\mathrm{~F}$ & 7.45 & 6.86 & -1.89 & -2.94 & 2.37 & 10.39 \\
$\mathbf{H}$ & $\mathbf{0 . 0 0}$ & $\mathbf{0 . 0 0}$ & $\mathbf{0 . 0 0}$ & $\mathbf{0 . 0 0}$ & $\mathbf{0 . 0 0}$ & $\mathbf{0 . 0 0}$ \\
$\mathrm{Me}$ & -1.19 & -1.43 & -0.16 & -0.45 & -0.81 & 1.26 \\
OMe & 2.75 & 1.79 & 0.96 & 0.69 & 1.55 & 2.07 \\
OH & 4.45 & 3.26 & 0.82 & -0.70 & 1.96 & 5.15 \\
$\mathrm{NH}$ & 5.24 & 3.62 & -1.60 & -4.41 & 0.71 & 9.65 \\
Range & 13.15 & 11.51 & 7.43 & 11.33 & & \\
Average & 1.58 & 1.40 & -0.75 & -0.41 & & \\
SD & 3.77 & 3.11 & 2.08 & 3.33 & &
\end{tabular}

requires further study. However, it should be emphasized that for $\mathrm{C} 8-\mathrm{X}$ derivatives of $3 \mathrm{H}$ and $1 \mathrm{H}$ tautomers, the substituent effect is stronger than that observed for $9 \mathrm{H}$ and $7 \mathrm{H}$, and the strongest occurring for the $3 \mathrm{H} \mathrm{C} 8-\mathrm{X}$ adenine series (slope $=$ $5.08 \pm 0.40$, Table S6†).

\section{The proximity effects}

The proximity effect is associated with interactions of the functional group/substituent with the neighboring groups or even with the hydrogen atom, and in some cases with lone electron pairs. Due to this type of interaction, the electronic

Table 4 Energy difference values, $\Delta E_{8-2}$ (eqn (4), in $\left.\mathrm{kcal} \mathrm{mol}^{-1}\right)$, of the studied $\mathrm{C} 8-\mathrm{X}$ and $\mathrm{C} 2-\mathrm{X}$ substituted purine (PU) tautomers

\begin{tabular}{lrrrrrr}
\hline & \multicolumn{1}{c}{$\Delta E_{8-2}$} & & & & & \\
\cline { 2 - 5 } $\mathrm{PU}$ & \multicolumn{1}{c}{$9 \mathrm{H}$} & \multicolumn{1}{c}{$7 \mathrm{H}$} & \multicolumn{1}{c}{$3 \mathrm{H}$} & \multicolumn{1}{c}{$1 \mathrm{H}$} & Average & Range \\
\hline $\mathrm{NO}_{2}$ & 0.70 & 1.04 & 1.49 & 2.56 & 1.45 & 1.86 \\
$\mathrm{CN}$ & 0.69 & 0.93 & -3.70 & -3.41 & -1.37 & 4.63 \\
$\mathrm{CHO}$ & -4.36 & -4.43 & 4.31 & 6.61 & 0.53 & 11.04 \\
$\mathrm{Cl}$ & 2.16 & 2.08 & -2.42 & -2.71 & -0.22 & 4.87 \\
$\mathrm{~F}$ & 6.19 & 6.15 & -3.08 & -3.89 & 1.34 & 10.08 \\
$\mathbf{H}$ & $\mathbf{0 . 0 0}$ & $\mathbf{0 . 0 0}$ & $\mathbf{0 . 0 0}$ & $\mathbf{0 . 0 0}$ & $\mathbf{0 . 0 0}$ & $\mathbf{0 . 0 0}$ \\
$\mathrm{Me}$ & -1.62 & -1.78 & -0.96 & -1.15 & -1.38 & 0.81 \\
OMe & 1.22 & 0.72 & -1.32 & -1.29 & -0.17 & 2.54 \\
OH & 3.16 & 2.13 & -1.56 & -2.29 & 0.36 & 5.45 \\
$\mathrm{NH}$ & 4.01 & 3.03 & -5.28 & -6.97 & -1.30 & 10.98 \\
Range & 10.55 & 10.58 & 9.59 & 13.58 & & \\
Average & 1.21 & 0.99 & -1.25 & -1.25 & & \\
SD & 2.95 & 2.82 & 2.73 & 3.73 & &
\end{tabular}




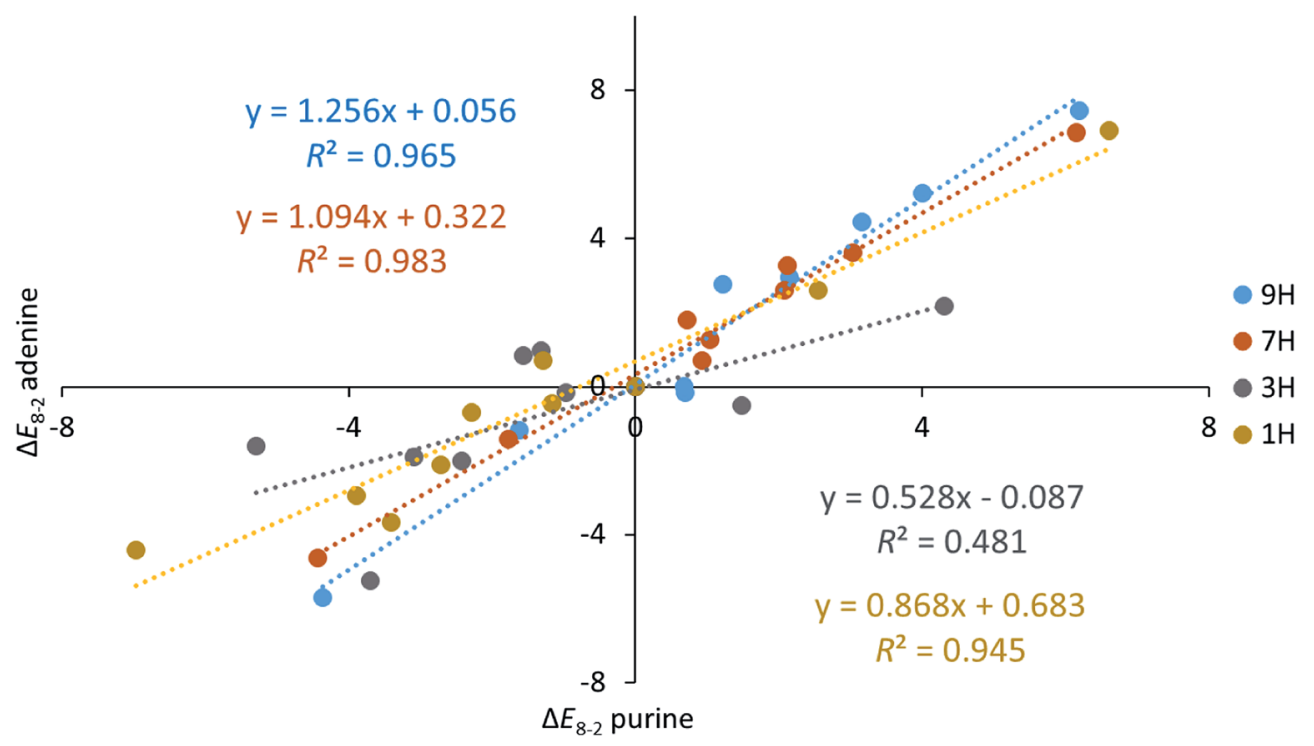

Fig. 3 Relations between the $\Delta E_{8-2}$ values (in kcal mol ${ }^{-1}$ ) obtained for adenine and purine tautomers.

properties of the group/substituent can be significantly modified. Applications of the substituent effect descriptors estimated for para- and meta- substituted benzoic acids, such as the $\sigma$ constants, to systems with proximity effects are usually not resulting with satisfactory correlations or even fail. ${ }^{43-45}$ Sayyed and Suresh $^{46}$ showed that the use molecular electrostatic potential and a molecular fragment approach in conjunction with a rotation experiment on the $\mathrm{COOH}$ group of benzoic acid allowed quantifying the effects of proximity.

In the case of substituted adenine derivatives, the proximity effects appear frequently, and some examples are presented in detail below. As mentioned above, for C2- or C8- substituted adenines, depending on the type of tautomers, the substituent can be in direct neighborhood of the lone pair on the nitrogen atom in the plane of the molecule (or two such pairs) and the $\mathrm{NH}$ with the $2 \mathrm{p}_{z}$ electron lone pair. Thus, some tautomers of adenine with asymmetric substituents, for example $\mathrm{C} 8-\mathrm{CHO}$ in $7 \mathrm{H}$ and $9 \mathrm{H}$ and

Table 5 Obtained SESE pu values for C2 and C8 substituted adenine tautomers

\begin{tabular}{|c|c|c|c|c|c|c|c|c|}
\hline \multirow[b]{2}{*}{$\mathrm{SESE}_{\mathrm{PU}}$} & \multicolumn{2}{|l|}{$9 \mathrm{H}$} & \multicolumn{2}{|l|}{$7 \mathrm{H}$} & \multicolumn{2}{|l|}{$3 \mathrm{H}$} & \multicolumn{2}{|l|}{$1 \mathrm{H}$} \\
\hline & C8-X & $\mathrm{C} 2-\mathrm{X}$ & C8-X & $\mathrm{C} 2-\mathrm{X}$ & C8-X & $\mathrm{C} 2-\mathrm{X}$ & C8-X & $\mathrm{C} 2-\mathrm{X}$ \\
\hline $\mathrm{NO}_{2}$ & 2.51 & 1.65 & 1.58 & 1.79 & 3.05 & 1.05 & 2.34 & 2.39 \\
\hline $\mathrm{CN}$ & 1.82 & 1.14 & 1.10 & 0.87 & 2.26 & 0.70 & 1.67 & 1.42 \\
\hline $\mathrm{CHO}$ & 1.86 & 0.52 & 1.27 & 1.06 & 2.05 & -0.09 & 2.06 & 2.36 \\
\hline $\mathrm{Cl}$ & -0.03 & 0.77 & 0.08 & 0.59 & -0.09 & 0.30 & -0.19 & 0.41 \\
\hline $\mathrm{F}$ & -0.45 & 0.81 & -0.16 & 0.56 & -0.68 & 0.51 & -0.69 & 0.26 \\
\hline $\mathbf{H}$ & 0.00 & 0.00 & 0.00 & 0.00 & 0.00 & 0.00 & 0.00 & 0.00 \\
\hline $\mathrm{Me}$ & -0.61 & -0.19 & -0.39 & -0.04 & -1.08 & -0.28 & -0.81 & -0.10 \\
\hline $\mathrm{OMe}$ & -1.73 & -0.19 & -0.90 & 0.17 & -2.93 & -0.64 & -2.09 & -0.12 \\
\hline $\mathrm{OH}$ & -1.58 & -0.29 & -0.73 & 0.41 & -2.63 & -0.44 & -1.71 & -0.12 \\
\hline $\mathrm{NH}_{2}$ & -1.79 & -0.56 & -0.98 & -0.39 & -4.21 & -0.53 & -2.91 & -0.35 \\
\hline Range & 4.30 & 2.22 & 2.56 & 2.18 & 7.26 & 1.69 & 5.26 & 2.74 \\
\hline Average & 0.00 & 0.37 & 0.09 & 0.50 & -0.43 & 0.06 & -0.23 & 0.62 \\
\hline SD & .57 & 2 & 3 & 0 & 2.40 & 0.56 & 9 & 1.05 \\
\hline
\end{tabular}

the $\mathrm{C} 2-\mathrm{CHO}$ in $1 \mathrm{H}$ and $3 \mathrm{H}$ systems, may exist in two conformations. One, with a low energy, when $\mathrm{CH}$ (from - $\mathrm{CHO}$ ) interacts with a lone pair and the $\mathrm{CO}$ part with the $\mathrm{NH}$, while in the second conformation, when $\mathrm{CHO}$ is rotated by $180^{\circ}$, strong repulsive interactions appear: $\mathrm{CO}$ is interacting with the lone pair and $\mathrm{CH}$ is interacting with $\mathrm{NH}$. The observed difference in energy between these two rotamers is $6.59,5.50,9.53$ and $5.92 \mathrm{kcal} \mathrm{mol}^{-1}$, respectively. Similar effects are observed for other nonsymmetric substituents, such as X $=\mathrm{OH}$ and OMe (Table S7 + ). These are examples of systems that can be obtained as energy molecule optimization results (local minima) and reveal possible interactions in the case of studied systems. Other substituents in the C2- and C8- position of adenine may have weaker proximity effects, but they still appear, and in many cases worse correlations with substituent constants or other substituent effect descriptors are observed. In this case, the proximity interactions $\mathrm{CO} \cdots \mathrm{HN}$ and $\mathrm{CH} \cdots \mathrm{N}$ (shown in Scheme 2) predominate the classical substituent effect based on resonance and inductive/field interactions. In other cases, this effect is not always significant, but it may contribute to lower values of determination coefficients, as shown in Table S6† and a few tables below.

Different interactions can be noticed in $\mathrm{N}$-substituted adenine derivatives. Here, the proximity effect is mainly observed for N7- and N1- substituted species, where amino group in the 6-position is neighboring to substituents. Good examples of proximity effects are intramolecular hydrogen bonds presented in Scheme 2b.

\section{SESE model based on reactions with benzene or aniline as references}

So far, substituted adenine and purine series, differing only in the $\mathrm{NH}_{2}$ group at $\mathrm{C} 6$, have been compared. One can ask how different are substituent effects observed in adenine and purine derivatives compared to those in benzene (BEN) and anilines (AN), which are considered classical objects in the SE research.

The corresponding equations are as follows:

$$
\mathrm{SESE}_{\mathrm{BEN}}=E_{9 \mathrm{H} \mathrm{AD}}+E_{\mathrm{X}-\mathrm{BEN}}-\left(E_{9 \mathrm{H} \mathrm{C} 8-\mathrm{X}-\mathrm{AD}}+E_{\mathrm{BEN}}\right)
$$



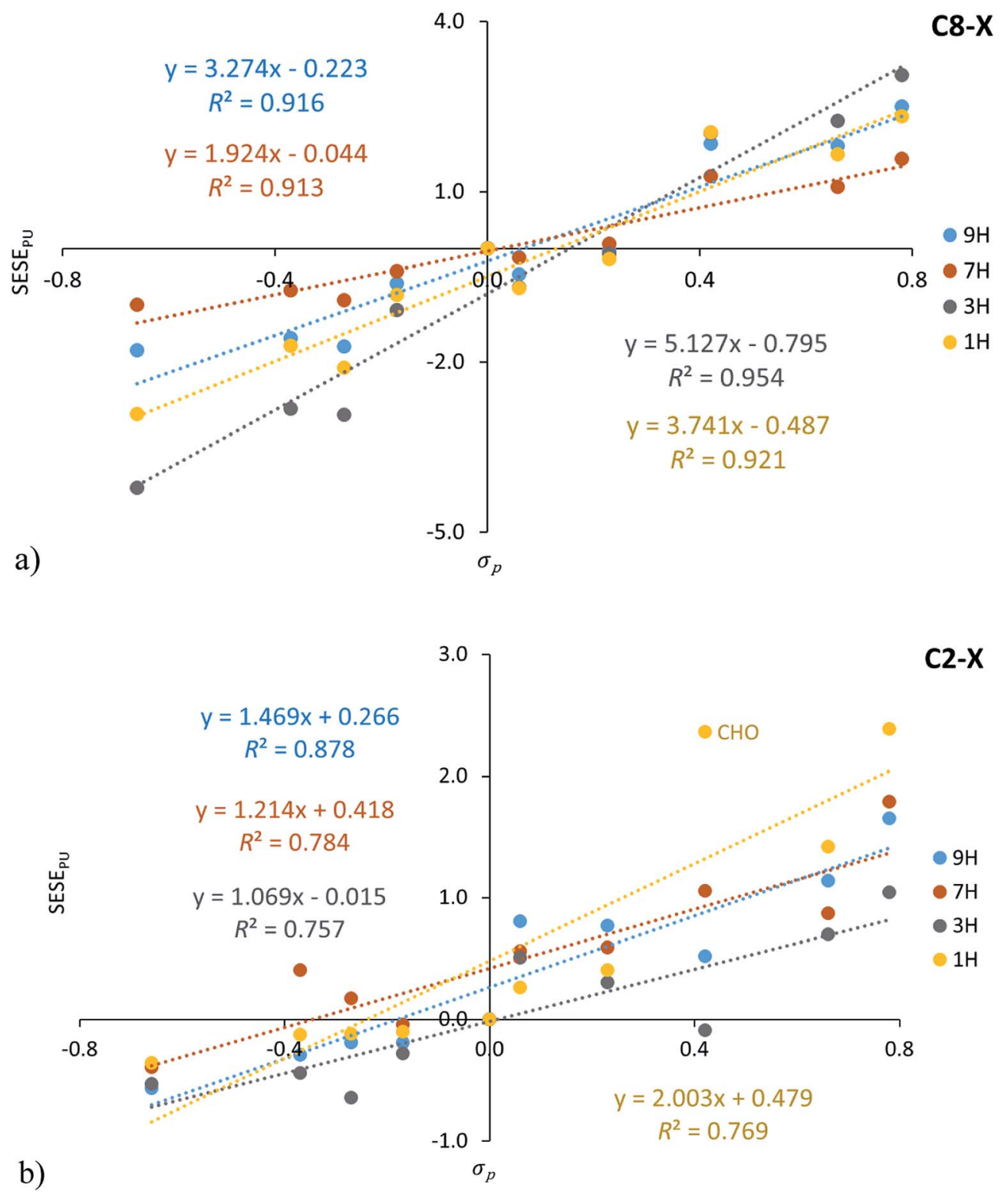

Fig. 4 Dependence of $\mathrm{SESE}_{\mathrm{PU}}$ (in kcal mol ${ }^{-1}$ ) on substituent constants $\sigma_{\mathrm{p}}$ for $\mathrm{C} 8-\mathrm{X}(\mathrm{a})$ and $\mathrm{C} 2-\mathrm{X}$ (b) positions of substituents in adenine systems.

$\mathrm{SESE}_{\mathrm{AN}}=E_{9 \mathrm{H} \mathrm{AD}}+E_{4-\mathrm{X}-\mathrm{AN}}-\left(E_{9 \mathrm{H} \mathrm{C} 8-\mathrm{X}-\mathrm{AD}}+E_{\mathrm{AN}}\right)$

Analogous equations can be written for the remaining substituted tautomers of adenine and purines. The obtained
(8) $\mathrm{SESE}_{\mathrm{BEN}}$ and $\mathrm{SESE}_{\mathrm{AN}}$ values are presented in Tables 6 and $\mathrm{S} 8, \uparrow$ respectively. It should be noted that the difference in values obtained for analogous derivatives of adenine and purines is SESE $_{\mathrm{PU}}$.<smiles></smiles>

7H C8: CHO-AD<smiles>O=C1NC2=NC=CC3=NC=C(N2)C13</smiles>

7H N7: CHO-AD<smiles></smiles>

1H C2: CHO-AD (a) (b) (c)

Scheme $2 \mathrm{CO} \cdots \mathrm{HN}$ interactions in selected formyl-adenine systems, with $\mathrm{O} \cdots \mathrm{H}$ distance marked in blue. 
In almost all cases the obtained values for both $\mathrm{SESE}_{\mathrm{BEN}}$ and SESE $_{\mathrm{AN}}$ are negative for electron-attracting substituents and positive for electron-donating ones. In addition, their absolute values are higher for purine systems than for adenine ones. This can be depicted by the slope of a linear relation of the SESE descriptors ( $\mathrm{SESE}_{\mathrm{BEN}}$ and $\mathrm{SESE}_{\mathrm{AN}}$ ) between the values for adenine and purine systems as shown in Table 7. Thus, the amino group of adenine reduces the influence of the substituent effect. Moreover, it can be noticed that this reduction is more visible for substitution at $\mathrm{C} 8-\mathrm{X}$ than at $\mathrm{C} 2-\mathrm{X}$. In all cases the discussed regressions are characterized by very high determination coefficients $\left(R^{2}>0.95\right)$.

Both $\mathrm{SESE}_{\mathrm{BEN}}$ and $\mathrm{SESE}_{\mathrm{AN}}$ are based on homodesmotic reactions with benzene derivatives as references. Thus, these descriptors, by definition, include a comparison of the substituent effect in heterocyclic systems (adenine or purine) with that realized in traditional benzene series (monosubstituted benzene or aniline derivatives). In the case of parasubstituted aniline derivatives, we can characterize the SE using

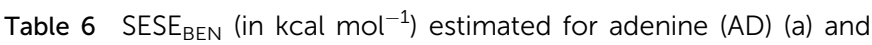
purine (PU) (b) with benzene as reference

\begin{tabular}{|c|c|c|c|c|c|c|c|c|}
\hline \multirow[b]{3}{*}{$\mathrm{AD}$} & \multicolumn{8}{|c|}{$\underline{S E S E}_{\mathrm{BEN}}$} \\
\hline & \multicolumn{2}{|l|}{$9 \mathrm{H}$} & \multicolumn{2}{|l|}{$7 \mathrm{H}$} & \multicolumn{2}{|l|}{$3 \mathrm{H}$} & \multicolumn{2}{|l|}{$1 \mathrm{H}$} \\
\hline & C8-X & $\mathrm{C} 2-\mathrm{X}$ & C8-X & $\mathrm{C} 2-\mathrm{X}$ & C8-X & $\mathrm{C} 2-\mathrm{X}$ & C8-X & $\mathrm{C} 2-\mathrm{X}$ \\
\hline $\mathrm{NO}_{2}$ & -4.71 & -4.87 & -6.03 & -4.78 & -4.44 & -4.95 & -4.93 & -2.33 \\
\hline $\mathrm{CN}$ & -4.07 & -4.06 & -5.12 & -4.42 & -1.49 & -6.75 & -1.90 & -5.55 \\
\hline $\mathrm{CHO}$ & 1.90 & -3.80 & 1.06 & -3.59 & -1.56 & 0.61 & -2.33 & $4.5 \mathrm{~s}$ \\
\hline $\mathrm{Cl}$ & -2.82 & 0.13 & -2.63 & -0.04 & -0.33 & -2.35 & 0.13 & -1.99 \\
\hline $\mathrm{F}$ & -1.85 & 5.60 & -1.38 & 5.48 & 2.76 & 0.87 & 3.71 & 0.77 \\
\hline $\mathbf{H}$ & 0.00 & 0.00 & 0.00 & 0.00 & 0.00 & 0.00 & 0.00 & 0.00 \\
\hline $\mathrm{Me}$ & 3.24 & 2.05 & 3.50 & 2.08 & 2.79 & 2.62 & 3.14 & 2.70 \\
\hline OMe & 4.41 & 7.17 & 6.01 & 7.80 & 5.74 & 6.71 & 6.82 & 7.51 \\
\hline $\mathrm{OH}$ & 4.06 & 8.51 & 5.64 & 8.90 & 6.26 & 6.90 & 7.95 & 7.26 \\
\hline $\mathrm{NH}_{2}$ & 2.98 & 8.21 & 4.46 & 8.08 & 6.30 & 4.00 & 8.42 & 4.00 \\
\hline Range & 9.13 & 13.38 & 12.03 & 13.68 & 10.73 & 13.65 & 13.35 & 13.06 \\
\hline Average & 0.31 & 1.89 & 0.55 & 1.95 & 1.60 & 0.77 & 2.10 & 1.70 \\
\hline SD & 3.47 & 5.22 & 4.34 & 5.34 & 3.74 & 4.55 & 4.64 & 4.29 \\
\hline
\end{tabular}

(b) $\quad \mathrm{SESE}_{\mathrm{BEN}}$

\begin{tabular}{|c|c|c|c|c|c|c|c|c|}
\hline \multirow[b]{2}{*}{ PU } & \multicolumn{2}{|l|}{$9 \mathrm{H}$} & \multicolumn{2}{|l|}{$7 \mathrm{H}$} & \multicolumn{2}{|l|}{$3 \mathrm{H}$} & \multicolumn{2}{|l|}{$1 \mathrm{H}$} \\
\hline & C8-X & $\mathrm{C} 2-\mathrm{X}$ & C8-X & $\mathrm{C} 2-\mathrm{X}$ & C8-X & $\mathrm{C} 2-\mathrm{X}$ & C8-X & $\mathrm{C} 2-\mathrm{X}$ \\
\hline $\mathrm{NO}_{2}$ & -7.22 & -6.53 & -7.61 & -6.57 & -7.49 & -6.00 & -7.27 & -4.72 \\
\hline CN & -5.89 & -5.20 & -6.22 & -5.29 & -3.75 & -7.45 & -3.57 & -6.98 \\
\hline $\mathrm{CHO}$ & 0.04 & -4.32 & -0.22 & -4.64 & -3.61 & 0.70 & -4.39 & 2.22 \\
\hline $\mathrm{Cl}$ & -2.79 & -0.64 & -2.71 & -0.63 & -0.24 & -2.65 & 0.32 & -2.40 \\
\hline $\mathrm{F}$ & -1.40 & 4.79 & -1.22 & 4.92 & 3.44 & 0.36 & 4.40 & 0.51 \\
\hline H & 0.00 & 0.00 & 0.00 & 0.00 & 0.00 & 0.00 & 0.00 & 0.00 \\
\hline $\mathrm{Me}$ & 3.86 & 2.24 & 3.90 & 2.12 & 3.87 & 2.90 & 3.95 & 2.80 \\
\hline $\mathrm{OMe}$ & 6.14 & 7.36 & 6.91 & 7.62 & 8.67 & 7.35 & 8.92 & 7.63 \\
\hline $\mathrm{OH}$ & 5.63 & 8.80 & 6.37 & 8.50 & 8.90 & 7.33 & 9.67 & 7.38 \\
\hline $\mathrm{NH}_{2}$ & 4.77 & 8.78 & 5.44 & 8.47 & 10.51 & 5.22 & 11.33 & 4.36 \\
\hline Range & 13.36 & 15.32 & 14.51 & 15.06 & 18.00 & 14.80 & 18.60 & 14.60 \\
\hline Average & 0.31 & 1.53 & 0.46 & 1.45 & 2.03 & 0.78 & 2.34 & 1.08 \\
\hline SD & 4.75 & 5.79 & 5.12 & 5.80 & 6.09 & 5.13 & 6.38 & 4.83 \\
\hline
\end{tabular}

Table 7 Slope values, $a$, and determination coefficients, $R^{2}$, of SESE $E_{\mathrm{BEN}}$ and $S E S E_{A N}$ relations between values obtained for adenine (AD) and purine (PU) tautomers with substituents at positions $\mathrm{C} 2-\mathrm{X}$ and $\mathrm{C} 8-\mathrm{X}$

\begin{tabular}{|c|c|c|c|c|}
\hline & \multicolumn{2}{|l|}{$\mathrm{C} 8-\mathrm{X}$} & \multicolumn{2}{|l|}{$\mathrm{C} 2-\mathrm{X}$} \\
\hline & $a$ & $R^{2}$ & $a$ & $R^{2}$ \\
\hline \multicolumn{5}{|c|}{$\operatorname{SESE}_{\mathrm{BEN}}(\mathrm{AD}) v s . \mathrm{SESE}_{\mathrm{BEN}}(\mathrm{PU})$} \\
\hline $9 \mathrm{H}$ & $0.712 \pm 0.058$ & 0.949 & $0.899 \pm 0.026$ & 0.994 \\
\hline $7 \mathrm{H}$ & $0.842 \pm 0.031$ & 0.989 & $0.918 \pm 0.025$ & 0.994 \\
\hline $3 \mathrm{H}$ & $0.612 \pm 0.022$ & 0.990 & $0.885 \pm 0.023$ & 0.990 \\
\hline $1 \mathrm{H}$ & $0.724 \pm 0.019$ & 0.995 & $0.871 \pm 0.062$ & 0.995 \\
\hline \multicolumn{5}{|c|}{$\operatorname{SESE}_{\mathrm{AN}}(\mathrm{AD}) v s . \operatorname{SESE}_{\mathrm{AN}}(\mathrm{PU})$} \\
\hline $9 \mathrm{H}$ & $0.774 \pm 0.026$ & 0.991 & $0.927 \pm 0.019$ & 0.997 \\
\hline $7 \mathrm{H}$ & $0.875 \pm 0.015$ & 0.998 & $0.938 \pm 0.018$ & 0.997 \\
\hline $3 \mathrm{H}$ & $0.708 \pm 0.014$ & 0.997 & $0.927 \pm 0.012$ & 0.998 \\
\hline $1 \mathrm{H}$ & $0.792 \pm 0.011$ & 0.998 & $0.881 \pm 0.037$ & 0.986 \\
\hline
\end{tabular}

their homodesmotic reaction with benzene, where energy, $\mathrm{SESE}_{\mathrm{AN}-\mathrm{BEN}}$, can be calculated as:

$$
\mathrm{SESE}_{\mathrm{AN}-\mathrm{BEN}}=E_{\mathrm{X}-\mathrm{BEN}}+E_{\mathrm{AN}}-\left(E_{4-\mathrm{X}-\mathrm{AN}}+E_{\mathrm{BEN}}\right)
$$

The obtained values are presented in Table S9. $\dagger$ In the same table, values from B3LYP/6-311++G(d,p) calculations from our previous paper, ${ }^{34}$ are also given. These values are congruous with the results calculated at B97D3/aug-cc-pvdz level of theory.

The use of the SESE concept, with appropriately selected reactions, allows the comparison of the influence of a transmission moiety on the substituent effect. Purine is a reference for $\mathrm{SESE}_{\mathrm{PU}}$, whereas benzene for $\mathrm{SESE}_{\mathrm{AN}-\mathrm{BEN}}$. The obtained results of linear relation $\operatorname{SESE}_{\mathrm{PU}}$ (adenine) vs. $\operatorname{SESE}_{\mathrm{AN}-\mathrm{BEN}}(-$ aniline), shown in Table 8, reveal: (i) a comparable transmission of the substituent effect only for $\mathrm{C} 8-\mathrm{X} 3 \mathrm{H}$ adenine (slope = $1.062 \pm 0.104$ ); (ii) a weaker transmission of the substituent effect by the purine moiety than by benzene in all other cases; and (iii) the substituent effect acting from the adenine C8 position is stronger than from the $\mathrm{C} 2$ position.

In conclusion, a subsequent study confirmed that the more significant effect is observed in adenine when the substituent is attached to the 5-membered ring (substitution at C8-X position).

\section{SESE model based on reactions with imidazole or pyrimidine as references}

Purine (adenine) can be formed by the fusion of pyrimidine ( $\mathrm{NH}_{2}$-pyrimidine) and imidazole rings. Therefore, it can be of interest how the substituent effects observed in adenine and purine derivatives differ from those in imidazole (IM) and amino-pyrimidine (PY), substituted in a similar topological environment as in the purine (adenine) molecules. For this purpose, appropriate homodesmotic reactions, for the $9 \mathrm{H}$ tautomer shown in Scheme 3 (analogous reactions can be written for $7 \mathrm{H}$ tautomer), are used. Their energy allow to calculate $\mathrm{SESE}_{\mathrm{IM}}$ and $\mathrm{SESE}_{\mathrm{PY}}$, both for adenine and purine $\mathrm{C} 8-\mathrm{X}$ and $\mathrm{C} 2-\mathrm{X}$ substituted series, respectively; for $9 \mathrm{H}$ adenine $\mathrm{C} 8-\mathrm{X}$ and $\mathrm{C} 2-\mathrm{X}$ derivatives, according to the following equations: 
Table 8 Slope values, $a$, and determination coefficients, $R^{2}$, of relation $\mathrm{SESE}_{\mathrm{PU}}(\mathrm{AD})$ vs. $\mathrm{SESE}_{\mathrm{AN}-\mathrm{BEN}}(\mathrm{AN})$ for $\mathrm{C} 2-\mathrm{X}$ and $\mathrm{C} 8-\mathrm{X}$ substituted adenine tautomers

\begin{tabular}{|c|c|c|c|c|}
\hline & \multicolumn{4}{|c|}{$\operatorname{SESE}_{\mathrm{PU}}(\mathrm{AD}) v s . \mathrm{SESE}_{\mathrm{AN}-\mathrm{BEN}}(\mathrm{AN})$} \\
\hline & \multicolumn{2}{|l|}{$\mathrm{C} 8-\mathrm{X}$} & \multicolumn{2}{|l|}{$\mathrm{C} 2-\mathrm{X}$} \\
\hline & $a$ & $R^{2}$ & $a$ & $R^{2}$ \\
\hline $9 \mathrm{H}$ & $0.710 \pm 0.037$ & 0.978 & $0.257 \pm 0.073$ & 0.609 \\
\hline $7 \mathrm{H}$ & $0.417 \pm 0.024$ & 0.975 & $0.236 \pm 0.058$ & 0.674 \\
\hline $3 \mathrm{H}$ & $1.062 \pm 0.104$ & 0.929 & $0.183 \pm 0.064$ & 0.502 \\
\hline $1 \mathrm{H}$ & $0.804 \pm 0.054$ & 0.966 & $0.455 \pm 0.054$ & 0.898 \\
\hline
\end{tabular}

$$
\begin{aligned}
& \mathrm{SESE}_{\mathrm{IM}}=E_{9 \mathrm{H} \mathrm{AD}}+\mathrm{E}_{\mathrm{C} 2-\mathrm{X}-\mathrm{IM}}-\left(E_{9 \mathrm{H} \mathrm{C} 8-\mathrm{X}-\mathrm{AD}}+E_{\mathrm{IM}}\right) \\
& \mathrm{SESE}_{\mathrm{PY}}=E_{9 \mathrm{H} \mathrm{AD}}+E_{\mathrm{C} 2-\mathrm{X}-\mathrm{PY}}-\left(E_{9 \mathrm{H} \mathrm{C} 2-\mathrm{X}-\mathrm{AD}}+E_{\mathrm{PY}}\right)
\end{aligned}
$$

Analogous equations can be used for the remaining $9 \mathrm{H}$ and $7 \mathrm{H}$ tautomers of adenine and purine. The obtained values are presented in Table 9.

For particular substituents, calculated $\mathrm{SESE}_{\mathrm{PY}}$ and $\operatorname{SESE}_{\mathrm{IM}}$ values have opposite signs. As in the case of $\mathrm{SESE}_{\mathrm{PU}}$, SESE $_{\mathrm{PY}}$ values are negative (i.e. destabilizing interactions) for electron-donating substituents and usually positive for the electron-attracting ones. The opposite changes apply to $\mathrm{SESE}_{\mathrm{IM}}$, that is for $\mathrm{C} 8 \mathrm{X}$. series both adenine and purine. Furthermore, the slopes of a linear relation of the SESE descriptors ( $\operatorname{SESE}_{\mathrm{IM}}$ and $\mathrm{SESE}_{\mathrm{PY}}$ ) between the values for adenine and purine (both $9 \mathrm{H}$ and $7 \mathrm{H}$ ) systems (Table 10) document that the amino group of adenine reduces the influence of the substituent effect. In addition, the substituent effect in the $\mathrm{C} 8-\mathrm{X}$ series is weaker than for the $\mathrm{C} 2-\mathrm{X}$ series and the discussed regressions are characterized by very high determination coefficients $\left(R^{2}>0.92\right)$.

\section{Relations between $\mathrm{SESE}_{\mathrm{BEN}}, \mathrm{SESE}_{\mathrm{AN}}, \mathrm{SESE}_{\mathrm{IM}}$ and $\mathrm{SESE}_{\mathrm{PY}}$ descriptors and Hammett $\sigma_{\mathrm{p}}$ constants}

Statistical details of the mutual dependences of SESE $E_{\mathrm{BEN}}$, $\mathrm{SESE}_{\mathrm{AN}}, \mathrm{SESE}_{\mathrm{IM}}$ and $\mathrm{SESE}_{\mathrm{PY}}$ on $\sigma_{\mathrm{p}}$ for $\mathrm{C} 8-\mathrm{X}$ and $\mathrm{C} 2-\mathrm{X}$ adenine and purine derivatives are presented in Table S10.†

It should be added that $\sigma_{\mathrm{p}}$ should be understood as the generally accepted characteristic of the substituent effect in cases where contributions from inductive/field and resonance effects are equal. ${ }^{47-49}$ The greater $R^{2}$ of the regression SESE vs. $\sigma_{\mathrm{p}}$, the interactions between substituents in adenine/purine series are more similar to those in benzene. This could mean that in the studied systems the classical resonance and inductive/field effects are realized nearly alike. For almost all cases in the adenine series $R^{2}$ values are worse than the ones in purines (Table S10†). This can be explained by the proximity effects of the $\mathrm{NH}_{2}$ group in adenine and thus more complex nature of interactions. Therefore, benzene (and pyrimidine) as a reference for the
SE description in adenine systems is clearly worse than in purines. However, if aniline (i.e. 4 -X-aniline) is a reference system, the determination coefficients improve, and $\mathrm{SESE}_{\mathrm{AN}}$ becomes a good SE characteristic in both adenine and purine series. The same applies to $\mathrm{SESE}_{\mathrm{IM}}$, but this descriptor can only be used for the $\mathrm{C} 8-\mathrm{X}$ series. In addition, better correlations of $\mathrm{SESE}_{\mathrm{AN}}$ with $\sigma_{\mathrm{p}}$ for $\mathrm{C} 8 \mathrm{-X}$ series than for $\mathrm{C} 2-\mathrm{X}$ indicate a greater role of the resonance effect in the first case.

Considering the slope absolute values and benzene (aniline) as a reference, for the purine derivatives the strength of the SE increases with the stability of tautomers for $\mathrm{C} 2-\mathrm{X}$ series, while opposite trends can be seen for C8-X systems. In the case of adenine derivatives, the picture is not so clear. In addition, again, lower absolute slope values in the second series may be related to the presence of the amino group in adenine.

\section{Classical substituent effect}

The classical or traditional SE is the most common studied type of interaction - the properties of the "reaction site" Y (the fixed group in the series) are related to the properties of the $\mathrm{X}$ substituent in the disubstituted $\mathrm{X}-\mathrm{R}-\mathrm{Y}$ system. In the case of studied adenine derivatives, the C6-amino group is the fixed group (Y), purine moiety can be defined as $\mathrm{R}$ and substituents (X) can be introduced at the $\mathrm{C} 2$ or $\mathrm{C} 8$ positions (Scheme 1). The relationships between $\operatorname{cSAR}\left(\mathrm{NH}_{2}\right)$ and $\mathrm{SESE}_{\mathrm{PUR}}$ (as the $\mathrm{SE}$ descriptor) for all studied adenine tautomers are shown in Fig. 5 (the obtained $\operatorname{cSAR}\left(\mathrm{NH}_{2}\right)$ values are gathered in Table S11†). In addition, statistics of these relations and others in which $\mathrm{SESE}_{\mathrm{BEN}}$ and $\mathrm{SESE}_{\mathrm{AN}}$ are used as the SE descriptor are presented in Table S12. $\dagger$

Obtained dependences of $\operatorname{cSAR}\left(\mathrm{NH}_{2}\right)$ on $\mathrm{SESE}_{\mathrm{PUR}}$ indicate an interesting difference between regressions for the $\mathrm{C} 8-\mathrm{X}$ and $\mathrm{C} 2-$ $\mathrm{X}$ series. It is important to note the high values of the determination coefficient (for $\mathrm{C} 8-\mathrm{X} R^{2} \geq 0.987$, for $\mathrm{C} 2-\mathrm{X} R^{2} \geq 0.875$ ), which entitle us to a deeper analysis. The variability of $\operatorname{cSAR}\left(\mathrm{NH}_{2}\right)$ sensitivity to the $\mathrm{SE}$ in the $\mathrm{C} 8-\mathrm{X}$ series is significantly greater (slopes varies from 0.012 to 0.027 ) than in the $\mathrm{C} 2-\mathrm{X}$ series (the slope ranges from 0.025 to 0.029 ). This discrepancy can be easily explained by resonance structures for these two systems, which resemble the interactions with electronattracting groups observed in the case of para and meta positions in the substituted aniline ${ }^{34}$ (or phenolate). ${ }^{50}$ Adenine $\mathrm{C} 8-\mathrm{X}$ derivatives resemble para-substitution in benzene, where the intramolecular charge transfer between the electron donating and electron accepting substituents can be described by canonical forms with charge separation, shown in Scheme 4. In the case of $\mathrm{C} 2-\mathrm{X}$ systems, this transfer requires the use of canonical forms with double charge separation (as for metanitrophenolate). In general, when the number of bonds between carbon atoms to which electron attracting and electron donating substituents are attached is odd, then a charge transfer occurs (as in para substituted benzene), if the number is even, then interactions are like those for meta substituted benzene. ${ }^{51}$ 
<smiles>[Y]c1nc2c(N)nc([TlH])nc2n1C</smiles>

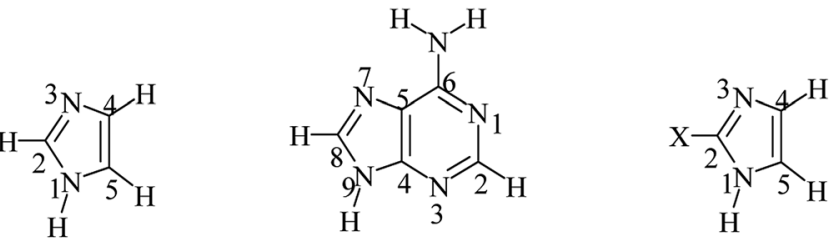

(a) for $\mathrm{C} 8 \mathrm{-X} \mathrm{AD}$

\section{8-X 9H adenine}

+ imidazole $=$

9H adenine<smiles>[1H]c1cc(N)ncn1</smiles><smiles></smiles>
$+\quad$ 2-X-imidazole

(b) for $\mathrm{C} 2-\mathrm{X} \mathrm{AD}$<smiles></smiles>

$+\quad$ amino-pyrimidine

$=\quad 9$ adenine<smiles>[X]c1nc([2H])cc([2H])n1</smiles>

\section{2-X $9 H$ adenine}<smiles>[X]c1cnc2nc([R])ncc2n1</smiles><smiles></smiles><smiles></smiles><smiles></smiles>

(c) for C8-X PU

8-X 9H purine

$$
+\quad \text { imidazole }
$$

$=$

9H purine

$+$

2-X-imidazole<smiles>[Y]c1nc([2H])c2nccnc2n1</smiles><smiles>c1cncnc1</smiles><smiles></smiles><smiles>[X]c1ccccn1</smiles>

(d) for C2-X PU

2-X 9H purine

$+\quad$ pyrimidine

$=$

9H purine $\quad+$

2-X-pyrimidine

Scheme 3 Homodesmotic reactions of adenine and purine with imidazole and aminopyrimidine (pyrimidine).

Table 9 SESE $_{I M}$ and SESE $E_{P Y}$ (in $\mathrm{kcal} \mathrm{mol}^{-1}$ ) values for adenine and purine $9 \mathrm{H}$ and $7 \mathrm{H}$ tautomers with imidazole (IM) and aminopyrimidine (PY) as references

\begin{tabular}{|c|c|c|c|c|c|c|c|c|}
\hline & \multicolumn{4}{|c|}{ Adenine } & \multicolumn{4}{|l|}{ Purine } \\
\hline & \multicolumn{2}{|c|}{$\mathrm{SESE}_{\mathrm{IM}}$} & \multicolumn{2}{|l|}{$\underline{\text { SESE}_{\mathrm{PY}}}$} & \multicolumn{2}{|c|}{ SESE $_{\text {IM }}$} & \multicolumn{2}{|l|}{$\mathrm{SESE}_{\mathrm{PY}}$} \\
\hline & $9 \mathrm{H}$ & $7 \mathrm{H}$ & $9 \mathrm{H}$ & $7 \mathrm{H}$ & $9 \mathrm{H}$ & $7 \mathrm{H}$ & $9 \mathrm{H}$ & $7 \mathrm{H}$ \\
\hline & C8-X & C8-X & $\mathrm{C} 2-\mathrm{X}$ & $\mathrm{C} 2-\mathrm{X}$ & $\mathrm{C} 8-\mathrm{X}$ & C8-X & $\mathrm{C} 2-\mathrm{X}$ & $\mathrm{C} 2-\mathrm{X}$ \\
\hline $\mathrm{NO}_{2}$ & -1.90 & -3.21 & 0.54 & 0.63 & -4.41 & -4.79 & 0.71 & 0.67 \\
\hline CN & -1.67 & -2.72 & 0.66 & 0.30 & -3.49 & -3.82 & 0.82 & 0.73 \\
\hline $\mathrm{CHO}$ & -1.77 & -2.62 & 0.80 & 1.01 & -3.63 & -3.89 & 1.51 & 1.19 \\
\hline $\mathrm{Cl}$ & 0.14 & 0.34 & -0.73 & -0.90 & 0.17 & 0.26 & -0.72 & -0.71 \\
\hline $\mathrm{F}$ & 0.92 & 1.40 & -1.16 & -1.27 & 1.37 & 1.55 & -1.18 & -1.05 \\
\hline H & 0.00 & 0.00 & 0.00 & 0.00 & 0.00 & 0.00 & 0.00 & 0.00 \\
\hline $\mathrm{Me}$ & 1.13 & 1.39 & -0.36 & -0.33 & 1.74 & 1.78 & -0.41 & -0.53 \\
\hline $\mathrm{OMe}$ & 2.44 & 4.03 & -1.68 & -1.05 & 4.17 & 4.93 & -1.53 & -1.26 \\
\hline $\mathrm{OH}$ & 1.95 & 3.54 & -1.88 & -1.49 & 3.53 & 4.27 & -1.20 & -1.50 \\
\hline $\mathrm{NH}_{2}$ & 2.62 & 4.10 & -1.57 & -1.70 & 4.41 & 5.08 & -1.82 & -2.12 \\
\hline Range & 4.52 & 7.32 & 2.68 & 2.72 & 8.82 & 9.87 & 3.34 & 3.31 \\
\hline Average & 0.35 & 0.57 & -0.49 & -0.44 & 0.35 & 0.49 & -0.35 & -0.42 \\
\hline SD & 1.64 & 2.66 & 0.98 & 0.90 & 3.12 & 3.52 & 1.06 & 1.04 \\
\hline
\end{tabular}

An another equivalent way of counting the bonds is the number of bonds between the electron-donating atom (group D, nitrogen this time) and the electron-accepting atom (group A, usually oxygen atom in the $\mathrm{NO}$ or $\mathrm{NO}_{2}$ groups or nitrogen atom in the $\mathrm{CN}$ group). In this case, if the number of all bonds between donating and accepting atoms in D and A groups, respectively, is even, then the charge transfer is privileged and well visible. ${ }^{52}$

Table 10 Slope values and determination coefficients of SESE $E_{I M}$ and $S E S E_{P Y}$ relations between values obtained for $9 \mathrm{H}$ and $7 \mathrm{H}$ adenine (AD) and purine $(\mathrm{PU})$ tautomers with substituents at positions $\mathrm{C} 8-\mathrm{X}$ and C2-X, respectively

\begin{tabular}{|c|c|c|}
\hline $\operatorname{SESE}_{\mathrm{IM}}(\mathrm{AD}) v s . \operatorname{SESE}_{\mathrm{IM}}(\mathrm{PU})$ & \multicolumn{2}{|c|}{$\operatorname{SESE}_{\mathrm{PY}}(\mathrm{AD}) v s . \mathrm{SESE}_{\mathrm{PY}}(\mathrm{PU}$} \\
\hline $\mathrm{C} 8-\mathrm{X}$ & \multicolumn{2}{|c|}{$\mathrm{C} 2-\mathrm{X}$} \\
\hline & & \\
\hline & & 0.925 \\
\hline & & 0.959 \\
\hline
\end{tabular}




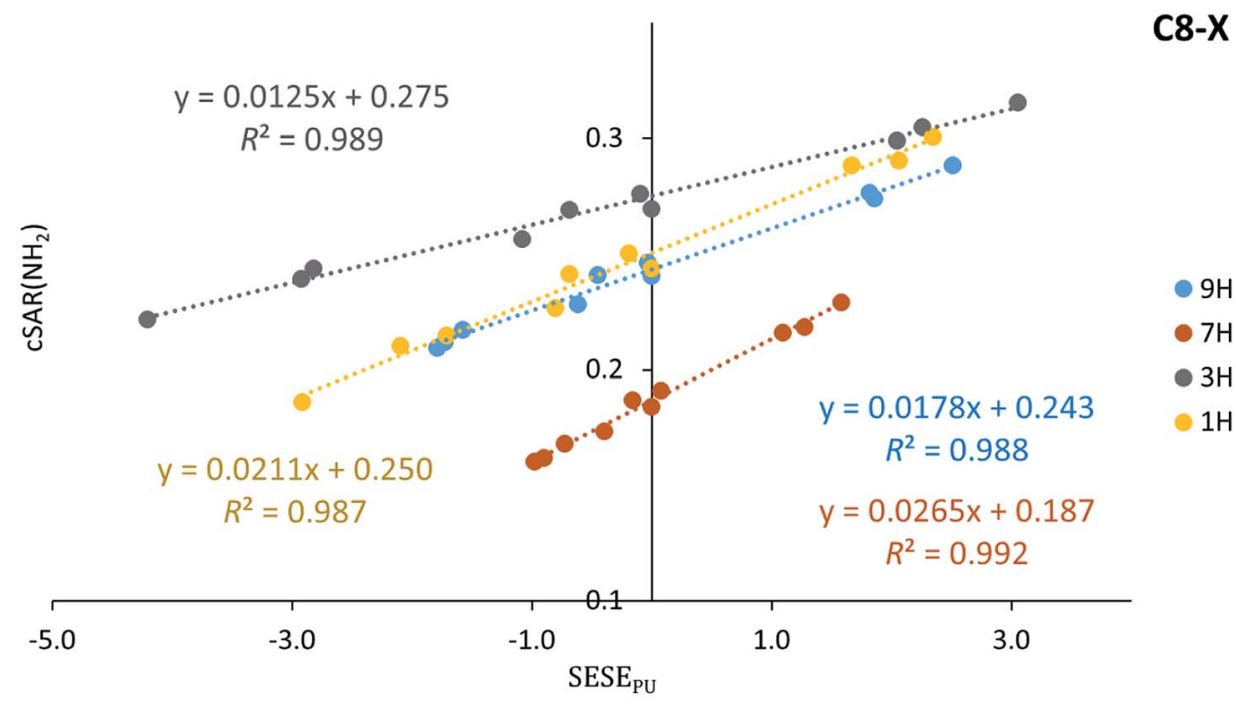

a)

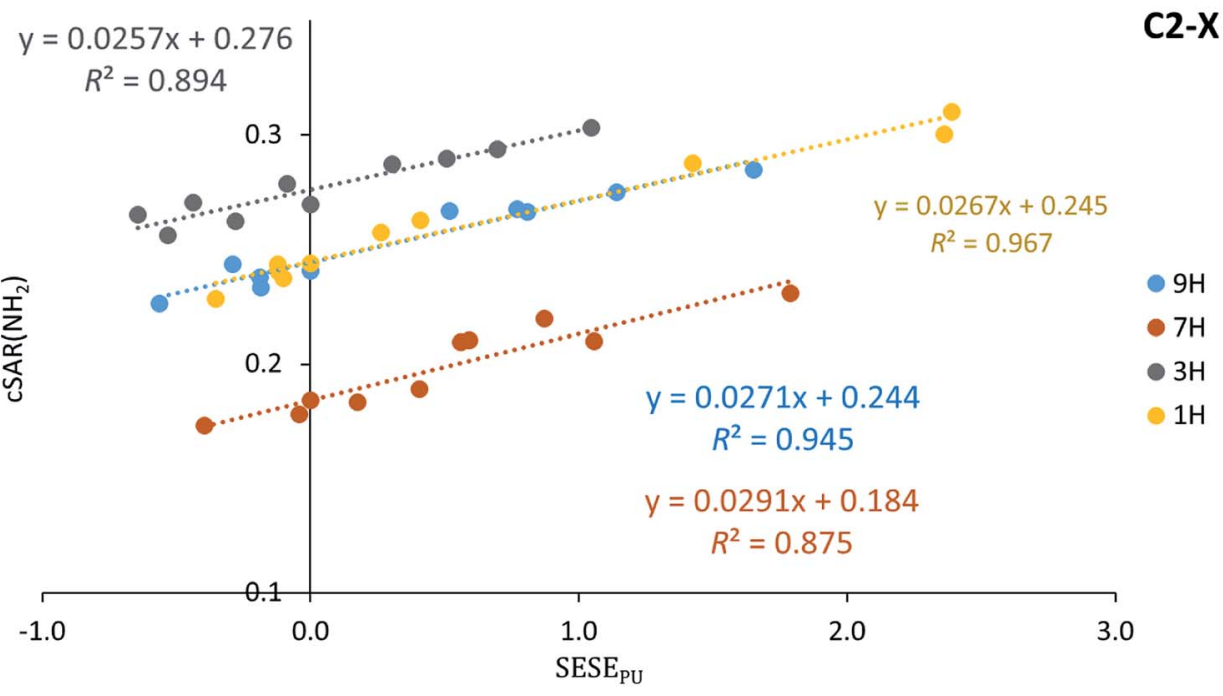

Fig. 5 Dependence of $\operatorname{cSAR}\left(\mathrm{NH}_{2}\right)$ on $\mathrm{SESE}_{\mathrm{PU}}$ (in $\mathrm{kcal} \mathrm{mol}^{-1}$ ) for the $\mathrm{C} 8-\mathrm{X}(\mathrm{a})$ and $\mathrm{C} 2-\mathrm{X}$ (b) substituted adenine series.

The above observation is confirmed by determination coefficients of $\operatorname{cSAR}\left(\mathrm{NH}_{2}\right)$ relation to $\mathrm{SESE}_{\mathrm{BEN}}$ and $\mathrm{SESE}_{\mathrm{AN}}$ (obtained with benzene derivatives as a reference). In the case of the $\mathrm{C} 8-\mathrm{X}$ series, they are higher than 0.857 (excluding $\mathrm{X}=\mathrm{CHO}$, Table $\mathrm{S} 12 \dagger)$, while in $\mathrm{C} 2-\mathrm{X}$ systems no correlation is observed,<smiles>NC1=NC(=[VH2])C=NC1=[TlH]</smiles>

Scheme 4 Intramolecular charge transfer from electron donating $\mathrm{NH}_{2}$ group to the electron attracting substituents. similarly as for substituted anilines in the para and meta positions, respectively. ${ }^{34}$

\section{Conclusions}

Adenine, the amino derivative of purine, is a building block of DNA and RNA helices. Both, purine and adenine, can exist in various tautomeric forms. Therefore, impact of the substituent on their stability is a very important problem.

The strength of the substituent effect was analyzed depending both on the type of tautomers as well as on the substitution positions in the adenine and purine derivatives. The application of energetic descriptor, SESE, based on homodesmotic reactions with various reference systems, allowed to investigate different aspects of the substituent effect.

For all substituted adenine and purine series, the $9 \mathrm{H}$ tautomeric systems are the most stable (the only exception is the N$\mathrm{NO}_{2} 9 \mathrm{H}$ purine), while the $1 \mathrm{H}$ tautomer systems are the least 
stable. In the case of $7 \mathrm{H}$ and $3 \mathrm{H}$ tautomers, the order of energy changes for substituted adenine derivatives differs from the sequences in purines, which can be explained by the presence (interaction) of the $\mathrm{NH}_{2}$ group. The amino group in adenine induces about 1.6 times greater energy difference between the most and least stable tautomers comparing to purine. In addition, substituents, except for the $\mathrm{N}-\mathrm{NO}_{2}$ systems, do not change stability of purine tautomers, which decreases in the order $9 \mathrm{H}$, $7 \mathrm{H}, 3 \mathrm{H}$ and $1 \mathrm{H}$.

The application of different reference systems in homodesmotic reactions and Hammett substituent constants reveals various similarity aspects in interaction due to the substituent effect.

The results of $\mathrm{SESE}_{\mathrm{rel}}$ (with respect to $9 \mathrm{H}$ tautomer) analysis indicate the stronger substituent effect in adenine than purine derivatives for substituents attached adjacent to the $\mathrm{NH}$ group of the ring. In addition, a more significant effect is observed in adenine systems when the substituent is attached to the 5membered ring. This observation is also confirmed by the results of analysis of the differences between the energies of pairs of the same molecule with the substituent at the $\mathrm{C} 8-\mathrm{X}$ and $\mathrm{C} 2-\mathrm{X}$ positions, for all tautomers.

The $\mathrm{SESE}_{\mathrm{PU}}$ (purine as reference) approach informs about changes in the substituent effect due to the presence of the amino group in adenine tautomers. Like in the substituted aniline derivatives, the obtained values show stabilizing and destabilizing interactions of the amino group with electronattracting and electron-donating substituents, respectively. Moreover, these interactions are more pronounced in $\mathrm{C} 8-\mathrm{X}$ than in the $\mathrm{C} 2-\mathrm{X}$ series.

The description of the substituent effect in adenines and purines based on their similarity to monocyclic reference systems (benzene, aniline, imidazole or pyrimidine) allows to conclude that the amino group of adenine reduces the effect of substituent when compared to purine. This weakening is more pronounced for the C8-X substitution, independently of the tautomer. However, it should be emphasized that these SESE values, with the exception of $\mathrm{SESE}_{\mathrm{PY}}$, suggest stabilizing interactions in the case of electron-donating substituents.

Dependences of SESE descriptors on the Hammett substituent constants allow to compare the similarity of the substituent effect in adenine (and purine) to that observed in benzene. The obtained relationships for $\mathrm{SESE}_{\mathrm{PU}}$ reveal the similarity of the substituent effect in $\mathrm{C} 8-\mathrm{X}$ to the para, while in $\mathrm{C} 2-\mathrm{X}$ to the meta positions in benzene (documented by very good correlations with $\sigma_{\mathrm{p}}$ and $\sigma_{\mathrm{m}}$, respectively). As in the case of aniline derivatives, ${ }^{34}$ the sensitivity of the amino group to the substituent effect, along with much better correlations, exhibit C8-X systems when compared to $\mathrm{C} 2-\mathrm{X}$ ones. In addition, weaker transmission of the substituent effect by the purine moiety than by benzene is observed.

Furthermore, analysis of the classical substituent effect in adenine confirms the more pronounced substituent effect from the C8-position what can be explained by the stronger resonance effect in such arrangements.

Specific interactions between substituents and neighboring $\mathrm{N}$ or $\mathrm{NH}$ are the reason for deviations and lower similarity of the substituent effect when compared with systems without these kind of interactions. Particularly strong deviations are observed for $\mathrm{CHO}$ group.

\section{Conflicts of interest}

The authors declare no competing financial interest.

\section{Acknowledgements}

We gratefully acknowledge the Interdisciplinary Center for Mathematical and Computational Modeling (Warsaw, Poland) and Wrocław Centre for Networking and Supercomputing (http://wcss.pl; grant No. 311) for providing computer time and facilities. Authors thank the National Science Centre and Ministry of Science and Higher Education of Poland for supporting this work under the grant no. UMO-2016/23/B/ST4/ 00082. P. H. M. would like to acknowledge Operational Project Knowledge Education Development 2014-2020 co-financed by European Social Fund.

\section{Notes and references}

1 W. Saenger, Principles of Nucleic Acids Structures, Springer, New York, 1990.

2 E. D. Raczyńska, M. Makowski, K. Zientara-Rytter, K. Kolczyńska, T. M. Stępniewski and M. Hallmann, J. Phys. Chem. A, 2013, 117, 1548-1559.

3 R. K. Singh, J. V. Oortiz and M. K. Mishra, Int. J. Quantum Chem., 2010, 110, 1901-1915.

4 E. D. Raczyńska, M. Makowski, M. Hallmann and B. Kaminska, RSC Adv., 2015, 5, 36587-36604.

5 Y. Kyogoku, R. C. Lord and A. Rich, Proc. Natl. Acad. Sci. U. S. A., 1967, 57, 250-257.

6 D. W. Miles, R. K. Robins and H. Eyring, J. Phys. Chem., 1967, 71, 3931-3941.

7 S. Diekman, E. von Kitzing, L. McLaughlin and J. Ott, Proc. Natl. Acad. Sci. U. S. A., 1987, 84, 8257-8261.

8 H. S. Koo and D. M. Krothers, Biochemistry, 1987, 26, 37453748.

9 T. F. Kagawa, M. L. Howell, K. Tseng and P. S. Ho, Nucleic Acids Res., 1993, 21, 5978-5986.

10 G. T. Hwang and F. E. Romesberg, Nucleic Acids Res., 2006, 34, 2037-2045.

11 C. Fonseca Guerra, T. van der Wijst and F. M. Bickelhaupt, ChemPhysChem, 2006, 7, 1971-1979.

12 A. C. Castro, M. Swart and C. Fonseca Guerra, Phys. Chem. Chem. Phys., 2017, 19, 13496-13502.

13 A. Ebrahimi, S. M. H. Khorassani, H. Delarmi and H. Esmaeeli, J. Comput.-Aided Mol. Des., 2010, 24, 409-416.

14 Y. L. Chen, D. Y. Wu and Z. Q. Tian, J. Phys. Chem. A, 2016, 120, 4049-4058.

15 V. Nikolova and B. Galubov, Maced. J. Chem. Chem. Eng., 2015, 34, 159-167.

16 T. M. Krygowski and B. T. Stępień, Chem. Rev., 2005, 105, 3482-3512.

17 L. P. Hammett, J. Am. Chem. Soc., 1937, 59, 96-103. 
18 L. P. Hammett, Physical Organic Chemistry, McGraw-Hill, New York, 1940, p. 196.

19 C. Hansch, A. Leo and R. W. Taft, Chem. Rev., 1991, 91, 165195.

20 O. Exner, in Advances in Linear Free Energy Relationships, ed. N. B. Chapman and J. Shorter, Plenum Press, London, 1972, ch. 1 , p. 1 .

21 C. D. Johnson, The Hammett Equation, Cambridge University Press, 1973.

22 J. Shorter, in Similarity Models in Organic Chemistry, Biochemistry and Related Fields, ed. R. I. Zalewski, T. M. Krygowski, and J. Shorter, Elsevier, Amsterdam, 1991, ch. 2, p. 77.

23 O. Exner and S. Böhm, Curr. Org. Chem., 2006, 10, 763-778.

24 W. J. Hehre, L. Radom, P. v. R. Schleyer and J. A. Pople, $A b$ initio Molecular Orbital Theory, J. Wiley\&Sons, N.Y., 1986.

25 S. M. Bachrach, Computational Organic Chemistry, John Wiley \& Sons, Inc., Hoboken, New Jersey, 2014.

26 P. George, M. Trachtman, C. W. Bock and A. M. Brett, J. Chem. Soc., Perkin Trans. 2, 1976, 11, 1222-1227.

27 A. Pross, L. Radom and R. W. Taft, J. Org. Chem., 1980, 45, 818-826.

28 M. K. Cyrański, Chem. Rev., 2005, 105, 3773-3811.

29 T. Siodla, W. P. Oziminski, M. Hoffmann, H. Koroniak and

T. M. Krygowski, J. Org. Chem., 2014, 79, 7321-7331.

30 T. M. Krygowski and N. Sadlej-Sosnowska, Struct. Chem., 2011, 22, 17-22.

31 N. Sadlej-Sosnowska, Chem. Phys. Lett., 2007, 447, 192-196.

32 N. Sadlej-Sosnowska and T. M. Krygowski, Chem. Phys. Lett., 2009, 476, 191-195.

33 O. A. Stasyuk, H. Szatylowicz, C. F. Guerra and T. M. Krygowski, Struct. Chem., 2015, 26, 905-913.

34 H. Szatylowicz, T. Siodla, O. A. Stasyuk and T. M. Krygowski, Phys. Chem. Chem. Phys., 2016, 18, 11711-11721.
35 T. Siodla, H. Szatylowicz, K. S. Varaksin and T. M. Krygowski, RSC Adv., 2016, 6, 96527-96530.

36 H. Szatyłowicz, A. Jezuita, T. Siodla, K. S. Varaksin, M. A. Domanski, K. Ejsmont and T. M. Krygowski, ACS Omega, 2017, 2, 7163-7171.

37 G. S. Remya and C. H. Suresh, Phys. Chem. Chem. Phys., 2016, 18, 20615-20626.

38 M. J. Frisch, G. W. Trucks, H. B. Schlegel, G. E. Scuseria, M. A. Robb, J. R. Cheeseman, G. Scalmani, V. Barone, B. Mennucci and G. A. Petersson, et al., Gaussian 09, Revision D.01, Gaussian Inc., Wallingford, CT, 2013.

39 P. H. Marek, H. Szatylowicz and T. M. Krygowski, Struct. Chem., 2019, 30, 351-359.

40 S. Grimme, S. Ehrlich and L. Goerigk, J. Comput. Chem., 2011, 32, 1456-1465.

41 J. D. Chai and M. Head-Gordon, Phys. Chem. Chem. Phys., 2008, 10, 6615-6620.

42 T. H. Dunning, J. Chem. Phys., 1989, 90, 1007-1023.

43 R. W. Taft, J. Am. Chem. Soc., 1953, 75, 4231-4238.

44 R. W. Taft, Steric Effects in Organic Chemistry, ed. M. S. Newman, Wiley, New York, 1956, p. 587.

45 M. Charton, Prog. Phys. Org. Chem., 1971, 8, 235-317.

46 F. B. Sayyed and C. H. Suresh, New J. Chem., 2009, 33, 24652471.

47 R. W. Taft and I. C. Lewis, J. Am. Chem. Soc., 1958, 80, 24362443.

48 R. W. Taft and I. C. Lewis, J. Am. Chem. Soc., 1958, 80, 53435352.

49 R. W. Taft, J. Phys. Chem., 1960, 64, 1805-1815.

50 M. Shahamirian, H. Szatylowicz and T. M. Krygowski, Struct. Chem., 2017, 28, 1563-1572.

51 T. M. Krygowski, M. Palusiak, A. Plonka and J. E. ZacharaHoreglad, J. Phys. Org. Chem., 2007, 20, 297-306.

52 H. Szatylowicz, T. M. Krygowski, M. Palusiak, J. Poater and M. Sola, J. Org. Chem., 2011, 76, 550-556. 